\title{
Effect of an Increase in Codend Mesh Size on Discarding in the Loligo Squid-Directed Fishery: A Commercial-Scale Test
}

\author{
Sarah E. King, Eric N. Powell' ${ }^{1}$, and Eleanor A. Bochenek \\ Haskin Shellfish Research Laboratory, Rutgers University, \\ 6959 Miller Ave., Port Norris, NJ 08349
}

\begin{abstract}
King, S. E., E. N. Powell, and E. A. Bochenek. 2009. Effect of an increase in codend mesh size on discarding in the Loligo squid-directed fishery: A commercial-scale test. J. Northw. Atl. Fish. Sci., 40: 41-58. doi:10.2960/J.v40.m631
\end{abstract}

\begin{abstract}
Discard reduction of juvenile fish and other unwanted bycatch species has been identified as a primary tool in achieving rebuilding and mortality objectives of current fishery management plans. Management of the offshore Loligo pealei squid fishery is particularly challenging because the legal codend mesh size is smaller than other regulated commercial fisheries. Co-occurrence of adult Loligo with juveniles and other Mid-Atlantic species of concern, coupled with the high volume of landings may lead to high discarding of non-target species. Accordingly, an increase in codend mesh size from the 2005 legal size of $1.875 "$ was evaluated as a means to reduce the capture of submarket-size squid, butterfish, and other species of concern, without materially impacting the catch of market-size squid. To evaluate the influence of fishing practice, a commercial-scale test was undertaken. A 2.5" mesh codend, in addition to the desired reduction of small Loligo, resulted in a substantial decrease in the catch of intermediate-size, but marketable $(10-13 \mathrm{~cm})$, squid without significant reduction in the bycatch of butterfish, silver hake or spiny dogfish. To recover total catch of market-size squid with the $2.5 \mathrm{"} \mathrm{mesh}$ codend would require an increase in fishing effort of $73.9 \%$. Even with that increase, total discards of small squid would be reduced by $52.7 \%$. However, total discards of bycatch species would be substantially increased. Codend mesh size is an effective option only if discarding of bycatch species is inconsequential or if avoidance of unwanted catch can be achieved through area management.
\end{abstract}

Keywords: bycatch, commercial test, discards, Loligo, codend, selectivity, squid.

\section{Introduction}

Discard reduction is a component of statutory requirements implemented by the "Sustainable Fisheries Act" Amendments to the Magnuson Stevens Fishery Conservation and Management Act (Anon., MS 1996). Approaches to managing discards have included gear modifications, area-time closures, and regulatory reform (e.g., Murawski, 1996; Lök et al., 1997; Karp et al., 2001). In the Mid-Atlantic, much effort has been directed at bycatch reduction in the small-mesh fisheries for squid (Loligo pealei) and silver hake (Merluccius bilinearis), emphasizing the reduced capture of juvenile scup (Stenotomus chrysops) (Kennelly, 1999; NEFSC, MS 2000; Glass et $a l ., 2002)$. However, a number of additional species discarded by small-mesh fisheries might also be a source of concern. One of these, butterfish (Peprilus triacanthus), has gained prominence recently because discarding in the
Loligo fishery is considered a dominant source of fishing mortality (NEFSC, MS 2004).

Loligo pealei has a life span of less than one year (Brodziak and Macy, 1996). Growth rate is rapid and spawning occurs throughout the year (Macy and Brodziak, 2001). These squid migrate inshore in late spring (MayJune), supporting an inshore commercial fishery during the summer. The offshore commercial fleet capitalizes on L. pealei in late autumn and winter when these squid congregate along the outer continental shelf (Brodziak and Hendrickson, 1998).

For a number of target species, such as Loligo, silver hake, and butterfish, a substantial portion of total discards are juveniles too small to be marketed. Discarding of juveniles reduces the number of individuals that reach sexual maturity, thus impacting spawning biomass. 
Discards of Loligo, silver hake, and butterfish account for more than half of all discards in Loligo-targeted tows (Powell et al., MS 2003). Anecdotal information from fish processors suggests that an additional significant number of squid are also discarded ashore due to their small size. However, this wastage is counted as landings, not discards, and so represents an economic loss to the fishery as well as potentially a loss to population reproductive capacity. (Macy and Brodziak, 2001; Buresch et al., 2006). Accordingly, gear improvements directed at reducing the catch of small Loligo may positively impact the economics of the squid fishery and the population dynamics of the stock. Gear improvements may also help to address other important discard issues in this fishery, including discarding of juvenile scup, silver hake, and butterfish.

Previous studies examined codend selectivity for squid (Lange, 1980; Hastie, 1996), but those studies did not emphasize commercial-scale fishing activities. Powell et al. (2004) emphasized the need to evaluate effectiveness of gear in commercial application as increased tow times and catch volumes, plus vessel-to-vessel variations in fishing procedures can affect gear performance (e.g., Graham et al., 2004; Powell et al., 2004). Thus, the objective of this study is to determine, at a commercial scale, if an increase in codend mesh size from the 2005 legal size of $1.875^{\prime \prime}(4.76 \mathrm{~cm})$ to $2.5^{\prime \prime}(6.35 \mathrm{~cm})$ can effectively reduce the capture of submarket-size squid, butterfish, silver hake, and other species of concern, without impacting the catch of market-size squid.

\section{Methods}

\section{Field program}

The field protocol was designed to provide information on the likely variability in fishing performance among vessels, including differences in net design. As a consequence vessels fished their standard gear with the exception of varying codend mesh size (Table 1). However, due to financial limitations restricting total sample number, vessels chosen were of relatively similar size and fished relatively similar gear, namely millionaire nets. As a variety of nets are fished for Loligo, extrapolation of our results to a wider range of gear types should be done with caution.

Commercial tows are often $>2 \mathrm{hr}$, and catches are large. Catches of Loligo and other species are significantly affected by time-of-day (Serchuk and Rathjen, 1974; Walsh, 1988; Gillis, 1999; NEFSC, MS 2002). Thus we assumed that net performance would vary with catch size and time of day and that vessel effects might become more important as catch size increased. Accordingly, to detect vessel effects, two vessels were deployed in parallel under standard commercial conditions. Each vessel towed a codend with a mesh size of $1.875 "(\mathbf{A})$, hereafter termed the control codend, and the experimental $2.5 "$ mesh codend (B) in an offset $A B B A$ sequence, to allow pairwise comparisons to be made over a four tow sequence: $A_{1} A_{2}, B_{1} A_{2}, B_{1} B_{2}$, and $A_{1} B_{2}$, where the subscripts refer to the paired vessels. Parallel tows of equivalent duration were made to retain direct comparability between tows. Locations, gear deployment methodology, and tow speeds of 2.9-3.2 knots (5.4-5.9 $\left.\mathrm{km} \mathrm{h}^{-1}\right)$ were standard for the fishery. However, tows did not exceed 3 hours to assure minimally four tows per day. Tows were restricted to daylight hours only, as is typical for the fishery.

A total of 40 tows were taken during Feb-Apr 2005, and 40 more in Dec 2005 to evaluate mesh selectivity during the times of year when the offshore Loligo fishery occurs. However, between the two field programs, one of the vessels (Vessel II, Tables 1 and 2) incurred damage and was unavailable thereafter. Thus, a third vessel

TABLE 1. Vessel and gear description.

\begin{tabular}{|c|c|c|c|c|c|c|c|}
\hline & $\begin{array}{c}\text { Hull } \\
\text { length }\end{array}$ & Net Type & Headrope & Footrope & $\begin{array}{c}\text { Ground } \\
\text { Cable }\end{array}$ & Control Codend & $\begin{array}{c}\text { Experimental } \\
\text { Codend }\end{array}$ \\
\hline Vessel I & $23.47 \mathrm{~m}$ & Millionaire & $44.20 \mathrm{~m}$ & $\begin{array}{c}44.20 \mathrm{~m} \\
\text { (wire/rope) }\end{array}$ & $\begin{array}{c}82.30 \mathrm{~m} \\
\text { (cable/wire) }\end{array}$ & $\begin{array}{l}\text { Single twine diamond } \\
\text { hung } 4.92 \mathrm{~cm} \mathrm{mesh} \\
\text { with a } 15.10 \mathrm{~cm} \text { mesh } \\
\text { strengthener }\end{array}$ & $\begin{array}{l}\text { Single twine diamond } \\
\text { hung } 6.26 \mathrm{~cm} \text { mesh } \\
\text { with a } 15.14 \mathrm{~cm} \text { mesh } \\
\text { strengthener }\end{array}$ \\
\hline Vessel II & $22.89 \mathrm{~m}$ & Millionaire & $41.15 \mathrm{~m}$ & $\begin{array}{c}41.15 \mathrm{~m} \\
\text { (rubber cookies) }\end{array}$ & $\begin{array}{c}82.30 \mathrm{~m} \\
\text { (cable/wire) }\end{array}$ & $\begin{array}{l}\text { Single twine diamond } \\
\text { hung } 4.92 \mathrm{~cm} \mathrm{mesh} \\
\text { with a } 15.11 \mathrm{~cm} \text { mesh } \\
\text { strengthener }\end{array}$ & $\begin{array}{l}\text { Single twine diamond } \\
\text { hung } 6.46 \mathrm{~cm} \text { mesh } \\
\text { with a } 15.26 \mathrm{~cm} \text { mesh } \\
\text { strengthener }\end{array}$ \\
\hline Vessel III & $22.40 \mathrm{~m}$ & Millionaire & $41.15 \mathrm{~m}$ & $\begin{array}{c}41.15 \mathrm{~m} \\
\text { (rubber cookies) }\end{array}$ & $\begin{array}{c}82.30 \mathrm{~m} \\
\text { (cable/wire) }\end{array}$ & $\begin{array}{l}\text { Single twine diamond } \\
\text { hung } 4.92 \mathrm{~cm} \mathrm{mesh} \\
\text { with a } 15.11 \mathrm{~cm} \text { mesh } \\
\text { strengthener }\end{array}$ & $\begin{array}{l}\text { Single twine diamond } \\
\text { hung } 6.46 \mathrm{~cm} \text { mesh } \\
\text { with a } 15.26 \mathrm{~cm} \text { mesh } \\
\text { strengthener }\end{array}$ \\
\hline
\end{tabular}


participated in the paired experiment in December 2005 (Vessel III, Tables 1 and 2).

Vessel position and time were recorded at oneminute intervals using DGPS and a Vemco data logger recorded water temperature and depth every minute during the tow. These temperature/depth profiles permitted a relatively precise determination of time-on-bottom and time-off-bottom, thus permitting an accurate reconstruction of tow distance- and a direct evaluation of any differential in depth between parallel tows. Budgetary constraints did not permit use of door spread or net height sensors; however, as the vessels fished similar nets, total catch provided an adequate estimate of effort within and between paired tows.

For each tow, the catch was sorted and weights obtained for all caught species. When the catch was large, NMFS-approved sub-sampling protocols were employed. One hundred randomly selected lengths, catch permitting, were obtained on each tow for Loligo, scup, silver hake, butterfish, black sea bass, summer flounder, and male and female spiny dogfish. Catch numbers for any size class $c, n_{i}$, were estimated from:

$$
n_{c}=\frac{n_{s_{c}}}{w_{s_{c}}} w_{c}
$$

where $s_{c}$ is the value in the sub-sample measured and $w$ is weight.

\section{Statistical Analysis}

Exploratory analysis demonstrated differences in the magnitude of the total catch on each cruise due to temporal differences in the availability of squid. To control for the influence of time-of-year and the consequent necessary changes in the locations fished, catch weight for each species $j$ was standardized across all cruises using the species' global median catch weight for the standard 1.875" mesh codend, $C_{\text {Global }}$ :

$$
C_{S T D_{i, j}}=\frac{C_{\text {Global }_{j}} C_{T_{i, j}}}{C_{\text {Local }_{T_{j}}}}
$$

where $C_{S T D}$ is the standardized catch weight in $\mathrm{kg}^{\text {tow }}{ }^{-1}$, $C_{T_{i}}$ is the species' catch weight for trip $T$ tow $i$, and $C_{\text {Local }_{T}}$ is the within-cruise median catch weight per tow using the control codend on trip $T$. The global and withincruise median were used rather than the respective means because subsequently-described statistical analyses used nonparametric methods. Most statistical analyses focused on the difference in catches between parallel tows, $\Delta C_{S T D}$. $\Delta C_{S T D}$ is a difference between ratio estimators standardized for clarity to the global median. For any species $j$ and tow $i$, from equation (2):

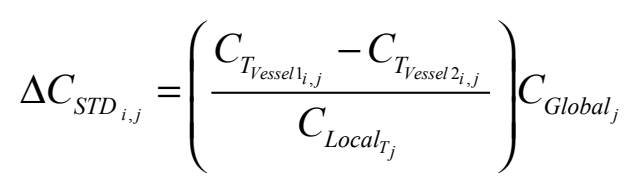

\begin{tabular}{|c|c|c|c|c|c|c|c|}
\hline & $\begin{array}{l}\text { Number } \\
\text { of tows }\end{array}$ & $\begin{array}{c}\text { Tow time } \\
\text { (h) }\end{array}$ & $\begin{array}{l}\text { Depth } \\
(\mathrm{m})\end{array}$ & $\begin{array}{l}\text { Tow speed } \\
\left(\mathrm{km} \mathrm{h}^{-1}\right)\end{array}$ & $\begin{array}{c}\text { Scope } \\
\text { (wire/depth) }\end{array}$ & $\begin{array}{c}\text { Bottom } \\
\text { temperature } \\
\left({ }^{\circ} \mathrm{C}\right)\end{array}$ & $\begin{array}{c}\text { Tow } \\
\text { total catch } \\
(\mathrm{kg})\end{array}$ \\
\hline \multicolumn{8}{|c|}{ Trip 1: 26-27 Feb 2005} \\
\hline Vessel I & 8 & 1.49 & 162.8 & 5.15 & 3.06 & 12.1 & 3209.4 \\
\hline Vessel II & 8 & 1.50 & 166.2 & 5.16 & 2.99 & 11.9 & 3701.4 \\
\hline \multicolumn{8}{|c|}{ Trip 2: 30 Mar-1 Apr 2005} \\
\hline Vessel I & 12 & 2.39 & 147.9 & 5.27 & 3.39 & 11.2 & 1775.9 \\
\hline Vessel II & 12 & 2.35 & 142.4 & 5.20 & 3.56 & 11.4 & 1662.3 \\
\hline \multicolumn{8}{|c|}{ Trip 3: 12-14 Dec 2005} \\
\hline Vessel I & 11 & 1.69 & 173.9 & 5.17 & 2.88 & 11.8 & 2014.8 \\
\hline Vessel III & 11 & 1.70 & 145.9 & 5.09 & 3.43 & 12.3 & 1421.5 \\
\hline \multicolumn{8}{|c|}{ Trip 4: 21-22 Dec 2005} \\
\hline Vessel I & 9 & 1.24 & 174.6 & 5.16 & 2.69 & 11.8 & 2161.8 \\
\hline Vessel III & 9 & 1.29 & 202.4 & 5.00 & 2.26 & 11.9 & 1652.6 \\
\hline
\end{tabular}

TABLE 2. Description of trips and tows. 
Thus, statistical analyses use catch ratios to minimize the influence of between-trip variations in availability expected to occur between seasons and locations.

The equivalent method was used to calculate the numbers of individuals caught per species per tow by replacing catch weight for catch in numbers in equation (2). In addition, total catch weight per tow and total catch minus Loligo catch per tow, respectively, were substituted for catch weight per tow in equation (2). A posteriori examination with ANOVA confirmed the absence of significant time-of-year or between-trip effects after standardization.

Because one objective was to evaluate whether an increase in mesh size would reduce bycatch of submarketsized Loligo, butterfish, silver hake, and spiny dogfish, the size frequency of each species was defined based on size classes of interest. Catch of Loligo in numbers was binned into market categories: $<10 \mathrm{~cm}$ (small), $10-13 \mathrm{~cm}$ (medium), and $\geq 13 \mathrm{~cm}$ (large). Dealers emphasized a desire to eliminate $<10 \mathrm{~cm}$ squid and to retain squid $\geq 13 \mathrm{~cm}$ without loss. The medium category represented the size range where some codend mesh selectivity was anticipated, but in which a large reduction in catch was not desired. Butterfish and silver hake were binned into $<12 \mathrm{~cm}$ (small) and $\geq 12 \mathrm{~cm}$ (large) categories based on size at $50 \%$ maturity for butterfish (Penttila et al., MS 1989; Cross et al., MS 1999) and fish age 1 and older for silver hake (Penttila et al., MS 1989). Spiny dogfish were separated into pups $(<36 \mathrm{~cm})$ and adults $(\geq 36 \mathrm{~cm})$ (Rago et al., 1998). These values were scaled to the global median as defined in equation (2).

Because vessels fished in parallel, the difference in the standardized catch weight, Diff ( $\Delta C_{S T D}$ in equation (3)), between simultaneous tows was calculated for the four pair-wise net configurations $\left(\mathrm{A}_{1} \mathrm{~A}_{2}, \mathrm{~B}_{1} \mathrm{~A}_{2}, \mathrm{~B}_{1} \mathrm{~B}_{2}\right.$, and $\mathrm{A}_{1} \mathrm{~B}_{2}$ ):

$$
\begin{aligned}
& \text { Diff }_{A A \text { or } B B}=C_{A_{1}}-C_{A_{2}} \quad \text { OR } \quad C_{B_{1}}-C_{B_{2}} \\
& \operatorname{Diff}_{A B \text { or } B A}=C_{A_{1}}-C_{B_{2}} \quad \text { OR } \quad C_{A_{2}}-C_{B_{1}}
\end{aligned}
$$

where Diff ${ }_{A A \text { or } B B}$ is the difference in standardized species' catch weight $\left(\mathrm{kg} \mathrm{tow}^{-1}\right)$ for a given paired tow in which both vessels towed the same codend and Diff ${ }_{A B \text { or } B A}$ is the difference in standardized species' catch weight in which the one vessel towed the control codend and the other towed the experimental codend. $C_{A_{1}}$ and $C_{A_{2}}$ are the standardized species' catch weights as defined in equation (2) for a given paired tow on vessels 1 and 2, respectively, using the standard codend $(A) . C_{B_{1}}$ and
$C_{B_{2}}$ are the standardized species' catch weights, defined in equation (2), for a given paired tow on vessels 1 and 2 , respectively, using the experimental codend $(B)$. Equation (4) was employed under the expectation that the two vessels would operate equivalently when fishing the same codend mesh size. Equation (5) was employed under the expectation that catch would decline with the 2.5 " codend; thus $B$ was always subtracted from $A$. Null hypotheses formulated with paired tows $A A$ and $B B$ were two-tailed. Null hypotheses formulated with paired tows $A B$ and $B A$ were one-tailed. The equivalent method was used to calculate differences in the numbers of individuals caught of that species by replacing catch weight for catch in numbers in equations (4) and (5). In addition, the total catch weight per tow and total bycatch weight per tow, respectively, were substituted for catch weight per tow in equations (4) and (5).

Due to the variability in catch between tows, three basic types of non-parametric statistics were emphasized (Daniel, 1978; Conover, 1980; Sokal and Rohlf, 1998). The differential performance of the two vessels using the same gear was evaluated by ranked ANOVA, the differences between vessel catches calculated from equation (2) being ranked prior to the test. The null hypothesis was that the differential in catch between the two vessels fishing the same codend was not different, regardless of the codend simultaneously fished. Any bias in performance between the two vessels for either of the two codends would generate a significant difference in this test. We extended this test to consider $A B$ tows. In this case, we expected the differential in catch to be unbiased regardless of which vessel towed the $2.5^{\prime \prime}$ mesh codend. To identify cruise effects on catch statistics, a cruise main effect was included in this ANOVA. The cruise main effect conflates a set of confounding variables including location, time-of-year, and the change in the second vessel between the spring and autumn field programs. Ranked dependent catch variables included the species' catch weight, the number of individuals caught by species, the difference in standardized species' catch weight per paired tow, the difference in standardized number of individuals caught per paired tow per species and size class, the difference in total catch weight per paired tow, and the difference in total bycatch weight per paired tow.

A two-tailed Wilcoxon Signed-rank test was used to evaluate whether differences in species' catch weight between simultaneous tows using the same codend type ( $A A$ and $B B$ ) varied significantly from zero (Conover, 1980). The null hypothesis was that the difference between catches in a paired tow did not differ from zero. Thus, we expected performance on the two vessels with the two 
codends to be unbiased and, furthermore, we expected that both vessels' catch would be equivalent if the same codend mesh size was towed.

A one-tailed Wilcoxon Signed-rank test compared catches between paired tows with different codends $(A B$ or $B A$ ). The null hypothesis was that no difference in catch occurred against the alternative hypothesis that the 2.5 " codend caught fewer fish.

The binomial test (Conover, 1980) was used to evaluate a possible bias caused by a variable distribution in tow time or tow depth between tows with the two codend mesh configurations. A posteriori Tukey's Studentized Range tests were used to identify the location of significant differences within ranked ANOVAs. Unless otherwise noted, all tests were conducted at the $\alpha=0.05$ significance level.

A posteriori power analyses examined the power of the statistical tests comparing differences between codends. These analyses determined the likelihood of accurately rejecting a null hypothesis when the alternative hypothesis was correct (Thomas and Krebs, 1997). For each test, the effect size was calculated from the data and the power of the test was calculated for the significance level observed. For the ANOVAs, power analysis followed Faul et al. (2007) with Cohen's $f$ used for effect size (Cohen, 1988). Values are presented as $1-\beta$ for $\alpha \leq 0.05$ and as $\beta$ for $\alpha>0.05$. For the Wilcoxon Signed-rank test, power analysis was conducted for the less conservative sign test (Faul et al, 2007) and, therefore, values of $\beta$ or $1-\beta$ provided are conservative. Cohen's effect size $g$ was used as a measure of effect size (Cohen, 1988).

Size-frequency distributions were compared with ANOVA by first computing descriptive variables for each species for each tow; these were mean size, the percentiles of size $\left(25^{\text {th }}, 50^{\text {th }}, 75^{\text {th }}\right)$, the interquartile range, and the range. These dependent variables were ranked prior to analysis. Independent variables included codend mesh size, cruise, and the interaction term. For some tests, total catch was included as a covariate.

\section{Results}

\section{Descriptive statistics}

A total of 40 paired tows were successfully completed during four cruises, two of which took place during 26-27 February and 30 March-1 April 2005, and two during 12-14 December and 21-22 December 2005 (Table 2). Tows occurred on the offshore Loligo fishing grounds between Spencer and Baltimore Canyons (Fig. 1).
On average, tow times varied from $1.24-2.39 \mathrm{~h}$ and were longest during Trip 2 because more daylight hours were available during that trip (Table 2, Fig. 2). Mean depth ranged from 142-202 m. Mean tow speeds fell within $10 \%$ of the target tow speed of $5.56 \mathrm{~km} \mathrm{~h}^{-1}$ and Vessel III tended to tow at a slightly slower rate than Vessels I and II. Average scope, the amount of wire paid out (m) divided by the depth (m), ranged from 2.26-3.56. Bottom temperatures were fairly constant despite the difference in trip dates and depths fished, ranging from $11.2-12.3^{\circ} \mathrm{C}$ (Table 2 ). These average tow characteristics and their variability are typical of standard Loligo fishing operations with the exception that tow times may be biased low.

Seasonal changes in Loligo availability resulted in depths and tow times being unique for each cruise. Trip 1 was characterized by intermediate tow times and tow depths in comparison to the other trips (Fig. 2). Tows were longest during Trip 2 and depths tended to be shallower. Trip 3 had the most variable tow times and depths but, in general, both fell intermediate in comparison to other trips. Trip 4, which occurred when daylight was at its minimum, was characterized by the shortest and deepest tows (Fig. 2). Of 80 tows, only four outliers were apparent: two long tow times during Trip 1, one short tow time during Trip 2, and one unusually shallow tow during Trip 4 (Fig. 2). This incidence of outliers is not unusual (Bros and Cowell, 1987). These outliers were considered part of the normal variability associated with Loligo fishing trips and were retained for statistical analysis.

Total catch (kg) increased with tow time (Fig. 3). Spearman's $\rho$ was positive for all cruises. Although tow times averaged more than one hour longer during Trip 4 than during Trip 2, with Trips 1 and 3 in between, the range of total catches observed during all trips was similar(Fig. 3). Spearman's Rank Correlation revealed that total catch weight increased significantly with tow time for Trips 1 and 4 , however $(\alpha=0.05)$. Comparison to other catches showed that the two long and one short outlier tow times were not associated with unusually large or small catches, respectively.

The influence of a positive correlation between tow time and total catch, coupled with steep offshore depth gradients in the Mid-Atlantic, necessitated that tow times and tow depths be unbiased with respect to codend fished because vessels potentially might have fished simultaneously at different depths. Analysis showed that tow times and depths indeed were homogeneously distributed above and below the trip median tow time and depth for the two codend configurations on each vessel (Binomial test, $\alpha=0.05$ ). Thus, tow times and depths did not bias subsequent codend comparisons and the variability 


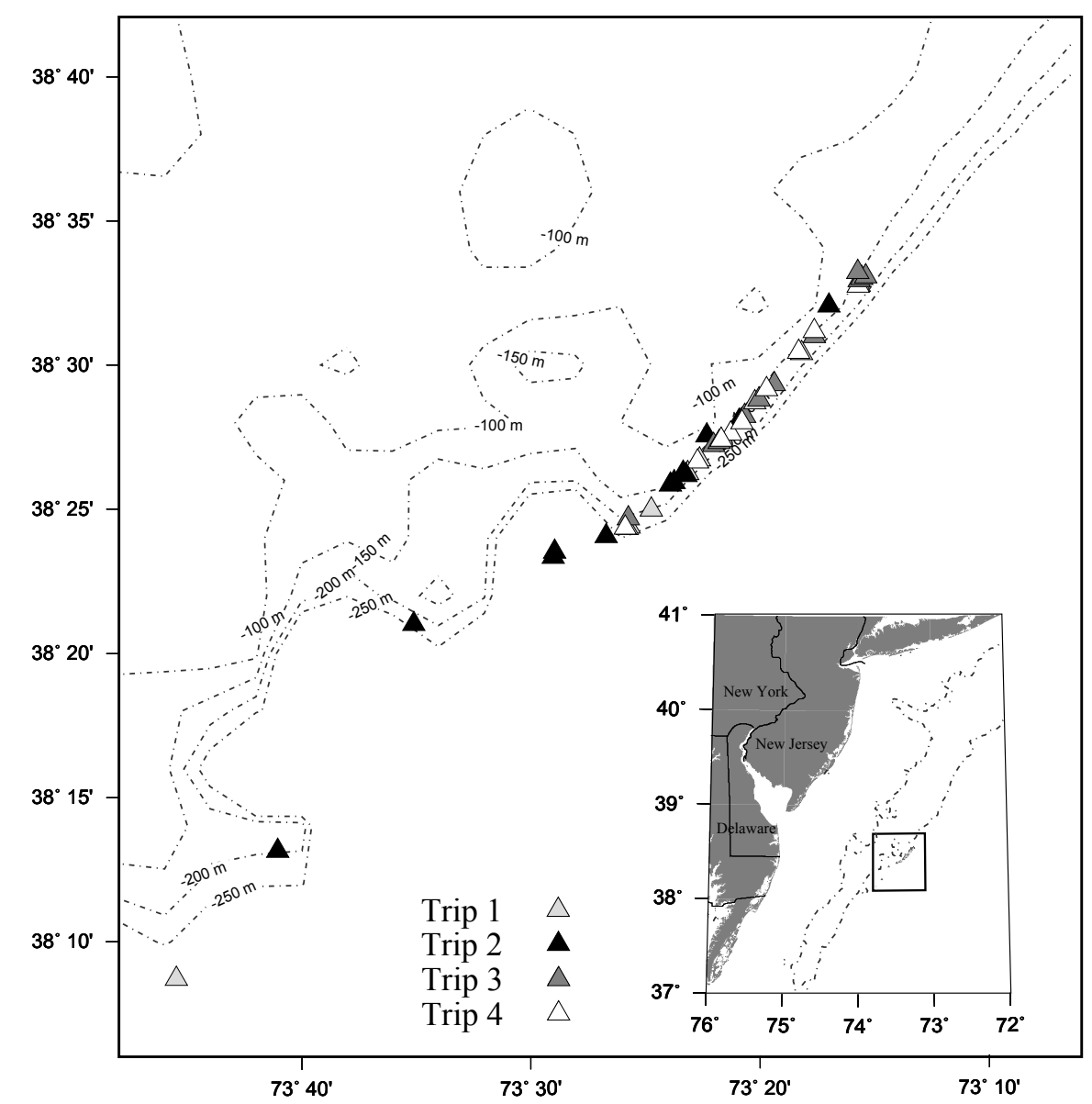

Fig. 1. Map of the Mid-Atlantic Bight between Spencer Canyon and Baltimore Canyon showing the locations of tows taken in this study.

is retained as part of the variance in the data without further correction. Differences in tow times and depths between cruises were considered part of the overall cruise effect (Figs. 2 and 3).

\section{Cruise effects on catch weight and number in paired tows}

Four species of commercial importance were caught with sufficient frequency for analysis: Loligo, butterfish, silver hake, and female and male spiny dogfish. Median catch in weight and numbers varied considerably over the cruises for Loligo and butterfish, and less so for silver hake and spiny dogfish (Tables 3 and 4). One cruise was associated with unusually high catches of silver hake (Trip 2) and male spiny dogfish (Trip 4). Remarkably, few spiny dogfish were captured on Trip 2. Catches were not obviously higher in the spring (Trips 1 and 2) in comparison to the winter (Trips 3 and 4) for Loligo. Catches of butterfish, and to a lesser extent silver hake, were higher in the Spring. The opposite was true for spiny dogfish with higher catches recorded in the following winter. Loligo comprised a majority of the catch during all trips. To minimize these cruise effects, catch weight and numbers caught were scaled to the global median catch for each species. ANOVA analysis confirmed the anticipated absence of significant differences in catch between cruises after standardization.

\section{Vessel effects on catch weight and number in paired tows}

Differences in catch between paired tows $H_{0}:$ Diff $_{A_{1} A_{2}}=$ Diff $_{B_{1} B_{2}}$. Furtheranalyses of catch weightand number focused on the difference in catch between paired tows. Ranked ANOVAs of paired tows using the same codend on each vessel $\left(A_{1} A_{2}\right.$ and $\left.B_{1} B_{2}\right)$ revealed that the two vessels performed equivalently for Loligo when both were towing the control codend ( $A A$ tows) or the experimental codend ( $B B$ tows). The differential in 


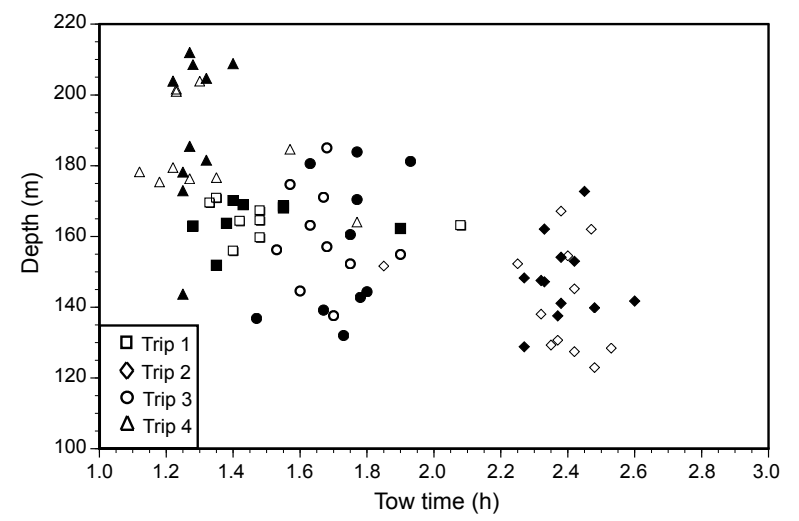

Fig. 2. Plot of tow depth (m) versus tow time (h). Control tows are represented by solid symbols and experimental tows are represented by open symbols.

catch between the two vessels was statistically similar regardless of which codend was towed, $A A$ or $B B$. This result was confirmed for catch weight, number, and number by size (Tables 5-7). Thus, vessel effects did not influence catch performance for Loligo.

Relative vessel performance when simultaneously towing control or experimental codends $(A A$ or $B B)$ did not differ significantly for other species either, regardless of species or size class (Tables 5-7). However, despite standardizing catch to the global median, some cruise effects still remained for catch weights of butterfish and spiny dogfish, and catch numbers for small butterfish and large male spiny dogfish (Tables 5-7). Vessel I caught relatively more butterfish than Vessel II in the February cruise (Trip 1) in comparison to the differential between Vessels I and III, in the December cruise (Trip 4) (Tukey's Studentized Range test, $\alpha=0.05$ ). For male and female spiny dogfish, Vessel I caught much less dogfish by weight, and for males, by number than Vessel II in February (Trip 1) relative to the catch differential observed between Vessels I and III in December (Trip 4). Thus, all significant cruise main effects originated in differences in catch between the two vessels in February relative to other trips. Interestingly, the same two vessels worked during Trip 2 (in late March), but without a similar differential. One reason for this disparity might be the absence of large dogfish catches during Trip 2. Equivalent differences did not exist between Vessel I and Vessel III that participated in Trips 3 and 4.

Differential catch between vessels $H_{0}:$ Diff $_{A_{1} A_{2}}=0$ and Diff $B_{B_{1} B_{2}}=0$. The differential in catch between vessels did not vary when towing the control or experimental codend, but did the vessels catch equivalently? Analysis of the vessel-effect tows in which the same

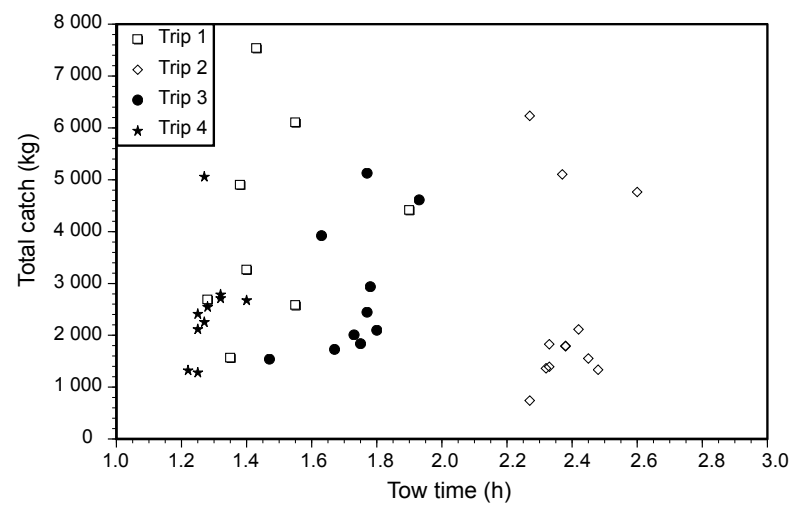

Fig. 3. Plot of total catch $(\mathrm{kg})$ versus tow time (h) for tows using the $1.875^{\prime \prime}$ mesh codend.

codend was towed by both vessels $\left(A_{1} A_{2}\right.$ and $\left.B_{1} B_{2}\right)$ indicated that differences in Loligo catch, by weight and numbers, when both vessels fished the control codend ( $A A$ tows) or when both vessels fished the experimental codend ( $B B$ tows) did not differ significantly from zero (Wilcoxon Signed-rank test, $\alpha=0.05$ ) (Tables 5 and 6). The same was true in the analysis of small, medium, and large squid. Overall, only small butterfish offered a minor exception, but the power of this test was low (Table 7). Thus, the two vessels performed with equivalent bias when simultaneously towing the control or experimental codends.

Differential catch between codends $H_{0}:$ Diff $_{A_{1} B_{2}}=$ Diff $_{A_{1} B_{1}}$. The experimental codend was anticipated to catch differentially from the control codend, but did that difference depend on the vessel towing the experimental codend? An evaluation of paired tows using different codends on each vessel $\left(A_{1} B_{2}\right.$ and $\left.A_{2} B_{1}\right)$ using ranked ANOVAs revealed that the relationship in catch between codends was equivalent regardless of which vessel towed the experimental codend and which vessel towed the control codend. The relationship in catch between the $A_{1} B_{2}$ tows and $A_{2} B_{1}$ tows did not differ significantly for squid catch, in weight or by numbers (ranked ANOVA, $\alpha=0.05$ ) (Tables 5 and 6). Because this was true, combining the $A_{1} B_{2}$ tows and the $A_{2} B_{1}$ tows in some subsequent tests was justified.

The same result was obtained for other species by weight and number. The cruise effects for female and male spiny dogfish catch weight and large male spiny dogfish catch in numbers remained in the comparison of codendeffect tows in which one vessel towed the experimental codend and the other the control codend ( $A B$ and $B A)$, however (Tables 5-7). These consistent vessel-to-vessel differences in performance originated from the February 
cruise, during which time Vessel II consistently caught more male spiny dogfish than Vessel I (75\% of the codendeffect hauls on Vessel I caught no male spiny dogfish).

The only exception was that total catch tended to be higher when Vessel I towed the control codend (Table 5). This result was not corroborated by the trend in squid catch that dominated total catch and the statistical result was more significant when Loligo was removed from total catch (Table 5). Thus, the trend is primarily a function of total bycatch. This differential occurred because Vessel I catches averaged higher than Vessel III catches on both December cruises, but was not sufficient to compromise further analysis of bycatch species. This was the only observed vessel-to-vessel difference between Vessels I and III.

\section{Effect of codend on catch weight and number in}

paired tows. $H_{0}$ : Diff ${ }_{A_{1} B_{2}}=0$ and Diff ${ }_{A_{2} B_{1}}=0$. Analysis of the experimental tows $\left(A_{1} B_{2}\right.$ and $A_{2} B_{1}$ codend configurations) revealed that significantly less Loligo was caught by the larger mesh by both weight and numbers (Wilcoxon Signed-rank test, $\alpha=0.05$ ), regardless of which vessel fished the experimental codend (B) (Table 8, Fig. 4). Total catch, largely a function of Loligo catch, was also reduced significantly in the larger-mesh codend. When Loligo was removed from total catch, codend type no longer influenced catch (Table 8).

TABLE 3. The median catch weight and median number caught per tow for selected species using the 1.875 " control codend.

\begin{tabular}{|c|c|c|c|c|}
\hline Species & Trip 1 & Trip 2 & Trip 3 & Trip 4 \\
\hline \multicolumn{5}{|c|}{ Catch weight (kg) } \\
\hline Loligo squid & 2752.95 & 1581.10 & 1746.35 & 2154.75 \\
\hline Butterfish & 10.00 & 117.15 & 0.65 & 0.75 \\
\hline Silver hake & 3.25 & 48.90 & 2.80 & 2.95 \\
\hline $\begin{array}{l}\text { Female spiny } \\
\text { dogfish }\end{array}$ & 2.25 & 0.00 & 2.00 & 5.80 \\
\hline $\begin{array}{l}\text { Male spiny } \\
\text { dogfish }\end{array}$ & 1.75 & 0.00 & 19.05 & 74.95 \\
\hline \multicolumn{5}{|c|}{ Numbers caught } \\
\hline Loligo squid & 44409.00 & 20621.00 & 37830.50 & 20647.00 \\
\hline Butterfish & 178.00 & 1753.50 & 8.50 & 7.00 \\
\hline Silver hake & 29.00 & 466.00 & 20.00 & 18.50 \\
\hline $\begin{array}{l}\text { Female spiny } \\
\text { dogfish }\end{array}$ & 3.00 & 0.00 & 1.00 & 7.00 \\
\hline $\begin{array}{l}\text { Male spiny } \\
\text { dogfish }\end{array}$ & 2.00 & 0.00 & 14.50 & 55.00 \\
\hline
\end{tabular}

Significantly fewer small- and medium-size Loligo were caught by the larger mesh codend, regardless of which vessel towed the experimental codend (Wilcoxon Signed-rank test, $\alpha=0.05$ ) (Table 9, Fig. 5). The results for large squid $(>13 \mathrm{~cm})$ were inconsistent. Catch was reduced significantly by the larger mesh codend only when Vessel I towed the control codend and when the two codend combinations were combined. Thus, large Loligo tended to escape capture in the experimental codend but the difference in capture efficiency was small (Table 9, Fig. 5). Previous analyses suggest that the two vessels performed equivalently when towing the two codends; thus, the inconsistent statistical results likely were due to variance in the minor differences in catch between the two codend mesh sizes. For small and medium Loligo, the results are unequivocal. Towing the experimental codend resulted in a reduction in both catch weight and numbers of Loligo (Tables 8 and 9, Figs. 4 and 5).

For other species, with few exceptions, the experimental codend did not reduce catch weight or catch in numbers significantly (Tables 8 and 9, Figs. 6-9). Fewer large silver hake were caught (in weight and numbers) when Vessel I towed the control codend (Wilcoxon Signed-rank test, $\alpha=0.05$ ) (Tables 8 and 9). The catch weight and numbers of male spiny dogfish were significantly lower when Vessel I towed the experimental codend

TABLE 4. The median catch weight and median number caught per tow for selected species using the 2.5" experimental codend.

\begin{tabular}{|c|c|c|c|c|}
\hline Species & Trip 1 & Trip 2 & Trip 3 & Trip 4 \\
\hline \multicolumn{5}{|c|}{ Catch weight (kg) } \\
\hline Loligo squid & 1851.90 & 323.50 & 370.50 & 548.55 \\
\hline Butterfish & 68.70 & 28.90 & 0.40 & 1.10 \\
\hline Silver hake & 0.55 & 17.50 & 10.60 & 6.40 \\
\hline $\begin{array}{l}\text { Female spiny } \\
\text { dogfish }\end{array}$ & 7.95 & 0.65 & 4.05 & 3.80 \\
\hline $\begin{array}{l}\text { Male spiny } \\
\text { dogfish }\end{array}$ & 3.45 & 1.35 & 19.20 & 131.15 \\
\hline \multicolumn{5}{|c|}{ Numbers caught } \\
\hline Loligo squid & 28268.00 & 3555.50 & 5381.00 & 4999.00 \\
\hline Butterfish & 1035.00 & 594.00 & 7.50 & 8.00 \\
\hline Silver hake & 4.00 & 126.50 & 17.50 & 38.50 \\
\hline $\begin{array}{l}\text { Female spiny } \\
\text { dogfish }\end{array}$ & 13.50 & 1.00 & 3.00 & 4.00 \\
\hline $\begin{array}{l}\text { Male spiny } \\
\text { dogfish }\end{array}$ & 7.00 & 1.00 & 15.00 & 100.50 \\
\hline
\end{tabular}


TABLE 5. Results of ranked ANOVA and Wilcoxon Signed-rank tests on the differences in catch weight per paired tow for selected species. Vessel-effect tows were $A_{1} A_{2}$ and $B_{1} B_{2}$ codend combinations. Codend-effect tows were $A_{1} B_{2}$ and $\mathrm{A}_{2} \mathrm{~B}_{1}$ codend combinations. $\mathrm{A}$, control codend; $\mathrm{B}$, experimental codend. $\beta$ values are provided for non-significant results at $\alpha=0.05$. 1- $\beta$ values are given for significant results and are computed at $\alpha=0.05$ rather than at the reported probability level.

\begin{tabular}{|c|c|c|c|c|c|c|c|}
\hline Variable & Loligo squid & Butterfish & Silver hake & $\begin{array}{l}\text { Female spiny } \\
\text { dogfish }\end{array}$ & $\begin{array}{l}\text { Male spiny } \\
\text { dogfish }\end{array}$ & Total catch & $\begin{array}{l}\text { Total catch } \\
\text { minus Loligo } \\
\text { catch }\end{array}$ \\
\hline \multicolumn{8}{|l|}{$\begin{array}{l}\text { Vessel-effect tows } \\
\text { ANOVA: }\end{array}$} \\
\hline Codend & $\begin{array}{c}- \\
\beta=0.786\end{array}$ & $\begin{array}{l}- \\
\beta=0.857\end{array}$ & $\begin{array}{l}- \\
\beta=0.562\end{array}$ & $\begin{array}{l}- \\
\beta=0.942\end{array}$ & $\begin{array}{c}- \\
\beta=0.943\end{array}$ & $\begin{array}{l}- \\
\beta=0.802\end{array}$ & $\begin{array}{l}- \\
\beta=0.948\end{array}$ \\
\hline Cruise & $\begin{array}{c}- \\
\beta=0.906\end{array}$ & $\begin{aligned} P & =0.021 \\
1-\beta & =0.939\end{aligned}$ & $\begin{array}{l}- \\
\beta=0.742\end{array}$ & $\begin{array}{r}P=0.028 \\
1-\beta=0.831\end{array}$ & $\begin{aligned} P & =0.004 \\
1-\beta & =0.986\end{aligned}$ & $\begin{array}{c}- \\
\beta=0.856\end{array}$ & $\begin{array}{l}- \\
\beta=0.853\end{array}$ \\
\hline Codend $\times$ Cruise & $\begin{array}{c}- \\
\beta=0.226\end{array}$ & $\begin{aligned} P & =0.052 \\
1-\beta & =0.840\end{aligned}$ & $\begin{array}{c}- \\
\beta=0.739\end{array}$ & $\begin{array}{c}- \\
\beta=0.896\end{array}$ & $\begin{array}{c}- \\
\beta=0.760\end{array}$ & $\begin{array}{c}- \\
\beta=0.384\end{array}$ & $\begin{array}{c}- \\
\beta=0.576\end{array}$ \\
\hline \multicolumn{8}{|c|}{ WILCOXON SIGNED RANK TEST: } \\
\hline AA only & $\begin{array}{c}- \\
\beta=0.979\end{array}$ & $\begin{array}{c}- \\
\beta=0.979\end{array}$ & $\begin{array}{l}- \\
\beta=0.952\end{array}$ & $\begin{array}{c}- \\
\beta=0.984\end{array}$ & $\begin{array}{c}- \\
\beta=0.984\end{array}$ & $\begin{array}{c}- \\
\beta=0.979\end{array}$ & $\begin{array}{c}- \\
\beta=0.979\end{array}$ \\
\hline BB only & $\begin{array}{c}- \\
\beta=0.952\end{array}$ & $\stackrel{-}{\beta=0.851}$ & $\stackrel{-}{\beta=0.851}$ & $\begin{array}{c}- \\
\beta=0.984\end{array}$ & $\begin{array}{l}- \\
\beta=0.984\end{array}$ & $\begin{array}{l}- \\
\beta=0.952\end{array}$ & $\begin{array}{l}- \\
\beta=0.979\end{array}$ \\
\hline $\begin{array}{l}\text { AA and BB } \\
\text { combined }\end{array}$ & $\begin{array}{c}- \\
\beta=0.938\end{array}$ & $\begin{array}{c}- \\
\beta=0.873\end{array}$ & $\begin{array}{c}- \\
\beta=0.938\end{array}$ & $\begin{array}{c}- \\
\beta=0.987\end{array}$ & $\begin{array}{c}- \\
\beta=0.987\end{array}$ & $\begin{array}{c}- \\
\beta=0.938\end{array}$ & $\begin{array}{c}- \\
\beta=0.959\end{array}$ \\
\hline \multicolumn{8}{|c|}{$\begin{array}{l}\text { Codend effect tows } \\
\text { ANOVA: }\end{array}$} \\
\hline Codend & $\begin{array}{l}- \\
\beta=0.784\end{array}$ & $\begin{array}{c}- \\
\beta=0.558\end{array}$ & $\begin{array}{l}- \\
\beta=0.643\end{array}$ & $\stackrel{-}{\beta}=0.485$ & $\begin{array}{c}- \\
\beta=0.629\end{array}$ & $\begin{array}{r}P=0.035 \\
1-\beta=0.799\end{array}$ & $\begin{aligned} P & =0.006 \\
1-\beta & =0.975\end{aligned}$ \\
\hline Cruise & $\begin{array}{c}- \\
\beta=0.493\end{array}$ & $\begin{array}{l}- \\
\beta=0.551\end{array}$ & $\begin{array}{l}- \\
\beta=0.318\end{array}$ & $\begin{array}{r}P=0.013 \\
1-\beta=0.876\end{array}$ & $\begin{aligned} P & =0.040 \\
1-\beta & =0.748\end{aligned}$ & $\begin{array}{c}- \\
\beta=0.551\end{array}$ & $\begin{array}{l}- \\
\beta=0.471\end{array}$ \\
\hline Codend $\times$ Cruise & $\begin{array}{c}- \\
\beta=0.867\end{array}$ & $\begin{array}{c}- \\
\beta=0.851\end{array}$ & $\begin{array}{c}- \\
\beta=0.201\end{array}$ & $\begin{array}{c}- \\
\beta=0.430\end{array}$ & $\begin{array}{c}- \\
\beta=0.403\end{array}$ & $\begin{array}{c}- \\
\beta=0.713\end{array}$ & $\begin{array}{c}- \\
\beta=0.734\end{array}$ \\
\hline
\end{tabular}

- , not significant at $\alpha=0.05$.

(Tables 8 and 9). The same was true for the number of female spiny dogfish captured only when Vessel I towed the control codend (Table 8). These latter results were products of the lower spiny dogfish catches on Vessel I during Trip 1 (February), regardless of codend towed.

\section{Changes in size-frequencies}

Size-frequency distributions were expected to shift toward larger size classes in tows using the experimental codend. As expected, the percentiles $\left(25^{\text {th }}, 50^{\text {th }}\right.$, and $\left.75^{\text {th }}\right)$ and mean size of Loligo were significantly larger in tows using the experimental codend in comparison to tows using the control codend (ranked ANOVA, $\alpha=0.05$ ) (Tables 10 and 11). The interquartile range and range also increased. The size of fish available to the trawl changed from one cruise to another as anticipated by the dynamic nature of these species on the outer shelf (Jenson, 1965; Colvovoresses and Musick, 1983; Shepherd and Terceiro, MS 1994; Murawski, 1993). Cruise effects were significant in all analyses of the $25^{\text {th }}, 50^{\text {th }}$, and $75^{\text {th }}$ percentiles and mean size for all bycatch species, with the exception of female spiny dogfish (Table 10). Cruise effects were also found for the interquartile range and range for silver hake and butterfish size distributions (Table 10); however, for no bycatch species were the control and experimental codends significantly different for any size metric.

Total catch may influence the size-frequency distribution of species because fuller nets may limit the release of smaller-sized individuals. Total catch exerted a significant influence on size class in two species, Loligo and silver 
TABLE 6. Results of ranked ANOVA and Wilcoxon Signed-rank tests on the differences in numbers caught per paired tow for selected species. Vessel-effect tows were $A_{1} A_{2}$ and $B_{1} B_{2}$ codend combinations. Codend-effect tows were $\mathrm{A}_{1} \mathrm{~B}_{2}$ and $\mathrm{A}_{2} \mathrm{~B}_{1}$ codend combinations. $\mathrm{A}$, control codend; $\mathrm{B}$, experimental codend. $\beta$ values are provided for nonsignificant results at $\alpha=0.05$. $1-\beta$ values are given for significant results and are computed at $\alpha=0.05$ rather than at the reported probability level.

\begin{tabular}{|c|c|c|c|c|c|}
\hline Variable & Loligo squid & Butterfish & Silver hake & $\begin{array}{l}\text { Female spiny } \\
\text { dogfish }\end{array}$ & $\begin{array}{l}\text { Male spiny } \\
\text { dogfish }\end{array}$ \\
\hline \multicolumn{6}{|l|}{$\begin{array}{l}\text { Vessel-effect tows } \\
\text { ANOVA: }\end{array}$} \\
\hline Codend & $\beta=\overline{0} .741$ & $\beta=\overline{0} .915$ & $\beta=\overline{0} .343$ & $\beta=\overline{0} .926$ & $\begin{array}{c}- \\
\beta=0.949\end{array}$ \\
\hline Cruise & $\beta=\overline{0} .732$ & $\begin{array}{r}P=0.035 \\
1-\beta=0.893\end{array}$ & $\beta=\overline{0} .658$ & $\beta=\overline{0} .664$ & $\begin{aligned} P & =0.006 \\
1-\beta & =0.976\end{aligned}$ \\
\hline Codend $\times$ Cruise & $\begin{array}{r}P=0.013 \\
1-\beta=0.968\end{array}$ & $\beta=0.209$ & $\beta=\overline{0} .793$ & $\beta=\overline{0} .930$ & $\begin{array}{c}- \\
\beta=0.779\end{array}$ \\
\hline \multicolumn{6}{|c|}{ WILCOXON SIGNED RANK TEST: } \\
\hline AA only & $\beta=\overline{0} .624$ & $\begin{array}{c}- \\
\beta=0.952\end{array}$ & $\beta=\overline{0} .952$ & $\begin{array}{c}- \\
\beta=0.984\end{array}$ & $\begin{array}{c}- \\
\beta=0.984\end{array}$ \\
\hline BB only & $\beta=\overline{0} .979$ & $\beta=0.952$ & $\beta=\overline{0} .851$ & $\beta=\overline{0} .984$ & $\beta=\overline{0} .984$ \\
\hline $\begin{array}{l}\mathrm{AA} \text { and } \mathrm{BB} \\
\text { combined }\end{array}$ & $\beta=0.754$ & $\begin{array}{c}- \\
\beta=0.959\end{array}$ & $\begin{array}{c}- \\
\beta=0.938\end{array}$ & $\begin{array}{c}- \\
\beta=0.987\end{array}$ & $\begin{array}{c}- \\
\beta=0.987\end{array}$ \\
\hline \multicolumn{6}{|c|}{$\begin{array}{l}\text { Codend effect tows } \\
\text { ANOVA: }\end{array}$} \\
\hline Codend & $\beta=\overline{0} .769$ & $\beta=0.788$ & $\beta=\overline{0} .817$ & $\begin{array}{r}P=0.002 \\
1-\beta>0.999\end{array}$ & $\begin{array}{c}- \\
\beta=0.536\end{array}$ \\
\hline Cruise & $\begin{array}{c}- \\
\beta=0.777\end{array}$ & $\beta=0.543$ & $\beta=\overline{0} .386$ & $\beta=\overline{0} .915$ & $\begin{aligned} P & =0.017 \\
1-\beta & =0.881\end{aligned}$ \\
\hline Codend $\times$ Cruise & $\begin{array}{c}- \\
\beta=0.936\end{array}$ & 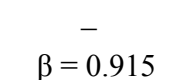 & $\beta=\overline{-} .392$ & $\beta=\overline{0} .738$ & $\begin{array}{c}- \\
\beta=0.464\end{array}$ \\
\hline
\end{tabular}

- , not significant at $\alpha=0.05$.

hake (Table 10). The results for Loligo are ambiguous because Loligo contributed the bulk of the catch and larger catches may simply be associated with the availability of smaller-sized squid. The cruise and codend main effects for Loligo related in Table 10 did not materially change if total catch was included as a covariate; therefore, the ambiguity did not compromise other inferences obtained from the statistical analysis. Silver hake never contributed materially to total catch; nevertheless, larger catches of smaller silver hake were associated with larger total catches. The weak relationship was driven by a tendency for a few tows yielding larger percentile sizes to be associated with tows with lower total catches (Fig. 10).

\section{Statistical Power}

We evaluated the confidence in the statistical results by calculating values of $\beta$ or 1- $\beta$ after Cohen (1988). For non-significant results, $\beta$ routinely fell above 0.70 .
Exceptions exist and these are reported in Tables 5-9; however, in most cases acceptance of the null hypothesis was associated with a satisfactory degree of confidence. For significant results, 1- $\beta$ values routinely fell above 0.75 and frequently exceeded 0.90 (Tables 5-9). Thus, the likelihood of incorrectly falsifying a null hypothesis was low for nearly all of the reported significant effects.

\section{Discussion}

The small-mesh fisheries of the Mid-Atlantic Bight are troublesome due to the perception, and often the reality, that these fisheries are responsible for substantial discarding of juvenile fish (Kennelly, 1999; Powell et al., 2004; Hendrickson, 2005). A small-mesh codend is a necessary design feature of nets used for the capture of squid because of their marketable size range (e.g., Lange, 1980; Hastie, 1996). Nevertheless, management of codend mesh size has 
rarely been pursued as a mechanism to address discarding, even of juvenile squid (Powell et al., 2004; Hendrickson, 2005). Recent concerns about the influence of the Loligo fishery on butterfish discard mortality and the desire on the part of dealers to reduce the volume of submarket-size squid landed led to the evaluation of mesh-size selectivity in this fishery.

Net selectivity studies vary widely in the number of replicate tows (e.g., Ragonese et al., 2001, 2002; Kynoch et al., 2004; Millar et al., 2004). Generally, tow-to-tow variability in catches is large. Luckily, large differences in catch are also desired outcomes. Net regulations resulting in small changes in catchability are not economically desirable and produce little advantage in sustainability of the stock. Accordingly, this study fielded a large number of tows to provide an adequate database.
Power analysis indicates that the number of tows resulted in unambiguous results with little probability of incorrectly accepting or falsifying a null hypothesis in nearly all statistical tests.

The study design included two critical components for increased applicability in management. First, tows were of commercial scale and used commercial fishing practices. The only compromises made were the restriction of tow lengths to $<3 \mathrm{hr}$ to permit minimally four tows per day and the restriction in the range of net designs used to millionaire nets. Second, the study explicitly included field programs covering a range of fishing seasons and used multiple vessels. These choices interposed a number of potential biases into the analysis, however. First was the possibility that experimental or control tows might be biased by depth or tow time. Statistical evaluation

TABLE 7. Results of ranked ANOVA and Wilcoxon Signed-rank tests on the differences in catch numbers per paired tow for selected size classes of Loligo squid. Vessel-effect tows were $A_{1} A_{2}$ and $B_{1} B_{2}$ codend combinations. Codend-effect tows were $A_{1} B_{2}$ and $A_{2} B_{1}$ codend combinations. $A$, control codend; $B$, experimental codend. $\beta$ values are provided for nonsignificant results at $\alpha=0.05 .1-\beta$ values are given for significant results and are computed at $\alpha=0.05$ rather than at the reported probability level.

\begin{tabular}{|c|c|c|c|c|c|c|c|c|}
\hline Variable & $\begin{array}{c}\text { Loligo } \\
\text { squid } \\
<10 \mathrm{~cm}\end{array}$ & $\begin{array}{c}\begin{array}{c}\text { Loligo } \\
\text { squid } \\
10-13 \mathrm{~cm}\end{array} \\
\end{array}$ & $\begin{array}{c}\text { Loligo } \\
\text { squid } \\
>13 \mathrm{~cm}\end{array}$ & $\begin{array}{l}\text { Butterfish } \\
<12 \mathrm{~cm}\end{array}$ & $\begin{array}{l}\text { Butterfish } \\
\geq 12 \mathrm{~cm}\end{array}$ & $\begin{array}{c}\begin{array}{c}\text { Silver } \\
\text { hake }\end{array} \\
\geq 12 \mathrm{~cm}\end{array}$ & $\begin{array}{c}\text { Femalespiny } \\
\text { dogfish } \\
\geq 36 \mathrm{~cm}\end{array}$ & $\begin{array}{c}\text { Male spiny } \\
\text { dogfish } \\
\geq 36 \mathrm{~cm}\end{array}$ \\
\hline \multicolumn{9}{|c|}{$\begin{array}{l}\text { Vessel-effect tows } \\
\text { ANOVA: }\end{array}$} \\
\hline Codend & $\begin{array}{c}- \\
\beta=0.790\end{array}$ & $\beta>0.661$ & $\begin{array}{c}- \\
\beta=0.936\end{array}$ & $\begin{array}{c}- \\
\beta=0.939\end{array}$ & $\begin{array}{c}- \\
\beta=0.949\end{array}$ & $\beta=\overline{0} .343$ & $\begin{array}{c}- \\
\beta=0.891\end{array}$ & $\begin{array}{c}- \\
\beta=0.916\end{array}$ \\
\hline Cruise & $\begin{array}{c}- \\
\beta=0.665\end{array}$ & $\begin{array}{c}- \\
\beta>0.644\end{array}$ & $\begin{array}{c}- \\
\beta=0.765\end{array}$ & $\begin{aligned} P & =0.018 \\
1-\beta & =0.908\end{aligned}$ & $\begin{array}{c}- \\
\beta=0.202\end{array}$ & $\beta=\overline{0} .658$ & $\begin{array}{c}- \\
\beta=0.530\end{array}$ & $\begin{aligned} P & =0.005 \\
1-\beta & =0.984\end{aligned}$ \\
\hline Codend $\times$ Cruise & $\begin{array}{c}- \\
\beta=0.467\end{array}$ & $\beta=0.260$ & $\begin{array}{c}- \\
\beta=0.638\end{array}$ & $\begin{array}{c}- \\
\beta=0.873\end{array}$ & $\begin{aligned} P & =0.029 \\
1-\beta & =0.913\end{aligned}$ & $\beta=\overline{0.793}$ & $\begin{array}{l}- \\
\beta=0.922\end{array}$ & $\begin{array}{c}- \\
\beta=0.744\end{array}$ \\
\hline \multicolumn{9}{|c|}{ WILCOXON SIGNED RANK TEST: } \\
\hline AA only & $\begin{array}{c}- \\
\beta=0.979\end{array}$ & $\beta>0.851$ & $\begin{array}{c}- \\
\beta=0.952\end{array}$ & - & $\begin{array}{c}- \\
\beta=0.979\end{array}$ & $\beta=\overline{0} .952$ & $\begin{array}{c}- \\
\beta=0.978\end{array}$ & $\begin{array}{c}- \\
\beta=0.978\end{array}$ \\
\hline BB only & $\beta=0.979$ & $\beta>0.952$ & $\begin{array}{c}- \\
\beta=0.979\end{array}$ & $\begin{array}{c}- \\
\beta=0.952\end{array}$ & $\begin{array}{c}- \\
\beta=0.952\end{array}$ & $\beta=\overline{0} .851$ & $\begin{array}{c}- \\
\beta=0.911\end{array}$ & $\begin{array}{c}- \\
\beta=0.978\end{array}$ \\
\hline $\begin{array}{l}\text { AA and BB } \\
\text { combined }\end{array}$ & $\begin{array}{c}- \\
\beta=0.959\end{array}$ & $\beta=0.754$ & $\begin{array}{c}- \\
\beta=0.938\end{array}$ & $\begin{array}{r}P=0.027 \\
1-\beta=0.150\end{array}$ & $\begin{array}{c}- \\
\beta=0.938\end{array}$ & $\beta=\overline{0.938}$ & $\begin{array}{l}- \\
\beta=0.927\end{array}$ & $\begin{array}{c}- \\
\beta=0.974\end{array}$ \\
\hline \multicolumn{9}{|c|}{$\begin{array}{l}\text { Codend effect tows } \\
\text { ANOVA: }\end{array}$} \\
\hline Codend & $\begin{array}{c}- \\
\beta=0.727\end{array}$ & $\begin{array}{c}- \\
\beta>0.793\end{array}$ & $\begin{array}{r}P<0.001 \\
1-\beta=0.999\end{array}$ & $\begin{array}{c}- \\
\beta=0.935\end{array}$ & $\begin{array}{c}- \\
\beta=0.689\end{array}$ & $\beta=\overline{0} .817$ & $\begin{array}{c}- \\
\beta=0.400\end{array}$ & $\begin{array}{c}- \\
\beta=0.461\end{array}$ \\
\hline Cruise & $\begin{array}{c}- \\
\beta=0.871\end{array}$ & $\beta>0.785$ & $\begin{array}{c}- \\
\beta=0.669\end{array}$ & $\begin{array}{c}- \\
\beta=0.329\end{array}$ & $\begin{array}{l}- \\
\beta=0.542\end{array}$ & $\beta=\overline{0} .386$ & $\begin{array}{l}- \\
\beta=0.904\end{array}$ & $\begin{aligned} P & =0.017 \\
1-\beta & =0.957\end{aligned}$ \\
\hline Codend $\times$ Cruise & $\begin{array}{c}- \\
\beta=0.664\end{array}$ & $\begin{array}{c}- \\
\beta>0.695\end{array}$ & $\begin{array}{c}- \\
\beta=0.793\end{array}$ & $\begin{array}{c}- \\
\beta=0.950\end{array}$ & $\begin{array}{c}- \\
\beta=0.908\end{array}$ & $\begin{array}{c}- \\
\beta=0.392\end{array}$ & $\begin{array}{c}- \\
\beta=0.940\end{array}$ & $\begin{array}{c}- \\
\beta=0.340\end{array}$ \\
\hline
\end{tabular}

-, not significant at $\alpha=0.05$; and $U$, undefined due to small sample size. 
TABLE 8. Results of the Wilcoxon Signed-rank tests on the differences in catch weight and numbers per codend-effect tow, $\mathrm{A}_{1} \mathrm{~B}_{2}$ and $\mathrm{A}_{2} \mathrm{~B}_{1}$ for selected species. $\mathrm{A}$, control codend; $\mathrm{B}$, experimental codend. $\beta$ values are provided for nonsignificant results at $\alpha=0.05$. 1- $\beta$ values are given for significant results and are computed at $\alpha=0.05$ rather than at the reported probability level.

\begin{tabular}{|c|c|c|c|c|c|c|c|}
\hline Variable & Loligo squid & Butterfish & Silver hake & $\begin{array}{c}\text { Female spiny } \\
\text { dogfish }\end{array}$ & $\begin{array}{c}\text { Male spiny } \\
\text { dogfish }\end{array}$ & Total catch & $\begin{array}{l}\text { Total catch } \\
\text { minus Loligo } \\
\text { catch }\end{array}$ \\
\hline \multicolumn{8}{|l|}{ Catch weight } \\
\hline AB only & $\begin{aligned} P & =0.002 \\
1-\beta & =0.736\end{aligned}$ & $\begin{array}{l}- \\
\beta=0.628\end{array}$ & $\begin{array}{r}P=0.007 \\
1-\beta=0.736\end{array}$ & $\begin{array}{l}- \\
\beta=0.912\end{array}$ & $\begin{array}{l}- \\
\beta=0.980\end{array}$ & $\begin{aligned} P & =0.003 \\
1-\beta & =0.736\end{aligned}$ & $\begin{aligned} P & =0.042 \\
1-\beta & =0.736\end{aligned}$ \\
\hline BA only & $\begin{aligned} P & =0.005 \\
1-\beta & =0.376\end{aligned}$ & $\begin{array}{l}- \\
\beta=0.954\end{array}$ & $\begin{array}{c}- \\
\beta=0.959\end{array}$ & $\begin{aligned} P & =0.031 \\
1-\beta & =0.335\end{aligned}$ & $\begin{array}{r}P=0.016 \\
1-\beta>0.999\end{array}$ & $\begin{aligned} P & =0.005 \\
1-\beta & =0.376\end{aligned}$ & $\begin{array}{c}- \\
\beta=0.954\end{array}$ \\
\hline $\begin{array}{l}\mathrm{AB} \text { and } \mathrm{BA} \\
\text { combined }\end{array}$ & $\begin{aligned} P & =0.001 \\
1-\beta & =0.933\end{aligned}$ & $\begin{array}{c}- \\
\beta=0.879\end{array}$ & $\begin{aligned} P & =0.054 \\
1-\beta & =0.617\end{aligned}$ & $\begin{array}{c}- \\
\beta=0.933\end{array}$ & $\begin{array}{c}- \\
\beta=0.603\end{array}$ & $\begin{array}{r}\mathrm{P}<0.001 \\
1-\beta=0.933\end{array}$ & $\begin{array}{l}- \\
\beta=0.755\end{array}$ \\
\hline \multicolumn{8}{|c|}{ Numbers caught } \\
\hline AB only & $\begin{array}{r}P=0.002 \\
1-\beta=0.736\end{array}$ & $\begin{array}{l}- \\
\beta=0.628\end{array}$ & $\begin{array}{r}P=0.024 \\
1-\beta=0.736\end{array}$ & $\begin{array}{r}P=0.016 \\
1-\beta>0.999\end{array}$ & $\begin{array}{l}- \\
\beta=0.980\end{array}$ & NA & NA \\
\hline BA only & $\begin{aligned} P & =0.001 \\
1-\beta & >0.999\end{aligned}$ & $\begin{aligned} &- \\
& \beta=0.954\end{aligned}$ & $\begin{aligned} &- \\
& \beta=0.959\end{aligned}$ & $\begin{array}{r}P=0.031 \\
1-\beta>0.999\end{array}$ & $\begin{aligned} P & =0.016 \\
1-\beta & >0.999\end{aligned}$ & NA & NA \\
\hline $\begin{array}{l}\mathrm{AB} \text { and } \mathrm{BA} \\
\text { combined }\end{array}$ & $\begin{aligned} P & =0.001 \\
1-\beta & >0.999\end{aligned}$ & $\begin{aligned} &- \\
& \beta=0.879\end{aligned}$ & $\begin{aligned}- & \\
\beta & =0.383\end{aligned}$ & $\begin{aligned}- & \\
\beta & =0.981\end{aligned}$ & $\begin{aligned} &- \\
& \beta=0.603\end{aligned}$ & NA & NA \\
\hline
\end{tabular}

-, not significant at $\alpha=0.05$; and NA, not applicable.

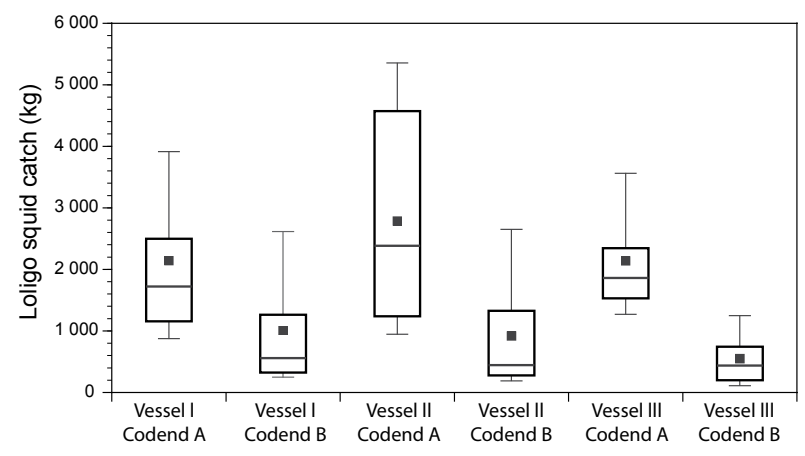

Fig. 4. Box and whisker plot of Loligo catch with (A) control and (B) experimental codends on three participating vessels. The box encompasses the interquartile range, with the median as the central line, the mean as the $\mathbf{~}$ and the whiskers as the range.

revealed no such biases. Second was the introduction of large variations in median catch size and composition of bycatch between field programs (e.g., Murawski, 1996). These differences were adequately resolved by standardizing catches between field programs.

The second component of study design was the decision to use paired tows (Powell et al., 2004; Hendrickson, 2005) to provide as unbiased an evaluation of vessel effects as possible while maintaining a commercial-scale test. Successful net regulations must be effective over a range of vessels, fishing at least somewhat differently. Powell et al. (2004) describe one such instance where vessel effects resulted in widely different results, in some cases undesirable, in comparison to regulatory goals. Thus, identification of potential vessel-to-vessel differences in performance is an important component of evaluating a mesh size change for the fishery and recognizes that commercial scale catches often influence the dynamics of gear selectivity (Graham et al., 2004) and that different vessels may influence fish behavior and catchability differentially (Handegard and Tjøstheim, 2005).

Vessel effects were limited in this study. Detailed evaluation of the relative performance of control and experimental nets revealed no significant differences in performance for the target species, Loligo. We examined the relative catchability between the two vessels with paired vessels towing each codend design simultaneously. We also examined the absolute differences in catch between vessels with paired vessels towing each codend design simultaneously. Finally, we examined the relative catchability between the two vessels with paired vessels towing the two different codend designs simultaneously. Vessel effects were identified in only two cases, for butterfish, and much more strongly for dogfish, where catches varied between Vessel I and Vessel II in February (Trip 1). In the most interesting case, Vessel I avoided the capture of dogfish nearly totally, in comparison to Vessel II, 
TABLE 9. Results of Wilcoxon Signed-rank tests on the differences in catch numbers per paired codend-effect tows $\left(A_{1} B_{2}\right.$ and $\left.A_{2} B_{1}\right)$ for selected size classes of Loligo squid, butterfish, silver hake and female and male spiny dogfish. A, control codend; $B$, experimental codend. $\beta$ values are provided for non-significant results at $\alpha=0.05$. $1-\beta$ values are given for significant results and are computed at $\alpha=0.05$ rather than at the reported probability level.

\begin{tabular}{|c|c|c|c|c|c|c|c|c|}
\hline Variable & $\begin{array}{l}\text { Loligo squid } \\
\quad<10 \mathrm{~cm}\end{array}$ & $\begin{array}{c}\text { Loligo squid } \\
10-13 \mathrm{~cm}\end{array}$ & $\begin{array}{l}\text { Loligo squid } \\
\quad>13 \mathrm{~cm}\end{array}$ & $\begin{array}{c}\text { Butterfish } \\
<12 \mathrm{~cm}\end{array}$ & $\begin{array}{l}\text { Butterfish } \\
\geq 12 \mathrm{~cm}\end{array}$ & $\begin{array}{l}\text { Silver hake } \\
\geq 12 \mathrm{~cm}\end{array}$ & $\begin{array}{c}\text { Female spiny } \\
\text { dogfish } \\
\geq 36 \mathrm{~cm}\end{array}$ & $\begin{array}{c}\text { Male spiny } \\
\text { dogfish } \\
\geq 36 \mathrm{~cm}\end{array}$ \\
\hline AB only & $\begin{aligned} P & =0.003 \\
1-\beta & =0.736\end{aligned}$ & $\begin{aligned} P & =0.002 \\
1-\beta & =0.736\end{aligned}$ & $\begin{array}{r}P=0.001 \\
1-\beta>0.999\end{array}$ & $\begin{array}{l}- \\
-\end{array}$ & $\begin{array}{c}- \\
\beta=0.628\end{array}$ & $\begin{aligned} P & =0.024 \\
1-\beta & =0.736\end{aligned}$ & $\begin{array}{c}- \\
\beta=0.980\end{array}$ & $\begin{array}{c}- \\
\beta=0.665\end{array}$ \\
\hline BA only & $\begin{aligned} P & =0.019 \\
1-\beta & =0.736\end{aligned}$ & $\begin{array}{r}P=0.001 \\
1-\beta>0.999\end{array}$ & $\begin{array}{c}- \\
\beta=0.989\end{array}$ & $\begin{array}{l}- \\
-\end{array}$ & $\beta=\overline{-} .954$ & $\begin{array}{c}- \\
\beta=0.959\end{array}$ & $\begin{array}{c}- \\
\beta=0.001\end{array}$ & $\begin{aligned} P & =0.016 \\
1-\beta & =0.999\end{aligned}$ \\
\hline $\begin{array}{l}\mathrm{AB} \text { and } \mathrm{BA} \\
\text { combined }\end{array}$ & $\begin{array}{r}P<0.001 \\
1-\beta=0.989\end{array}$ & $\begin{array}{r}P<0.001 \\
1-\beta>0.999\end{array}$ & $\begin{aligned} P & =0.027 \\
1-\beta & =0.617\end{aligned}$ & $\beta=\overline{0} .959$ & $\beta=\overline{0.879}$ & $\beta=0.383$ & $\begin{array}{c}- \\
\beta=0.603\end{array}$ & $\begin{array}{c}- \\
\beta=0.939\end{array}$ \\
\hline
\end{tabular}

- , not significant at $\alpha=0.05$.

during February. We can offer no explanation for this happenstance.

The bycatch-to-target species ratio, by weight, for butterfish, 0.0029; silver hake, 0.005; female dogfish, 0.050; and male dogfish, 0.017 are remarkably lower than what might be expected from previous discard estimates (e.g., Kennelly, 1999; Powell et al., 2004). These ratios are based on the total catch for all four cruises, but restricted only to tows with the control codend. The representativeness of the present data cannot be unequivocally demonstrated; however, the times, locations, vessel sizes, and gear used are not obviously outside the norm for the fishery. These low bycatch-to-target species ratios suggest that the Loligo fishery can be prosecuted much more cleanly than previous discard estimates would indicate to be the case. Powell et al. (2004) presented analogous results, also from the winter fishery in the Mid-Atlantic region. These two studies suggest that a more focused program evaluating case histories of high and low discarding in Loligo-targeted tows might provide guidance as to changes in fishing practice (e.g., Andrew and Pepperell, 1992) that might significantly reduce discarding in this smallmesh fishery.

As a consequence of the absence of vessel effects, catch of Loligo could be unambiguously evaluated. The 2.5" codend resulted in much reduced capture of squid, and this difference was dominated by a reduction in the catch of squid $<13 \mathrm{~cm}$ in size. However, the catch of $10-13 \mathrm{~cm}$ squid, a size range desired for landing, was also reduced. Catch of larger squid was reduced somewhat, but differences were of limited statistical significance. In comparison to squid, the experimental codend did not differ significantly from the control codend in catch, by weight or number, for any other investigated species, even if statistical analysis was limited to the smaller

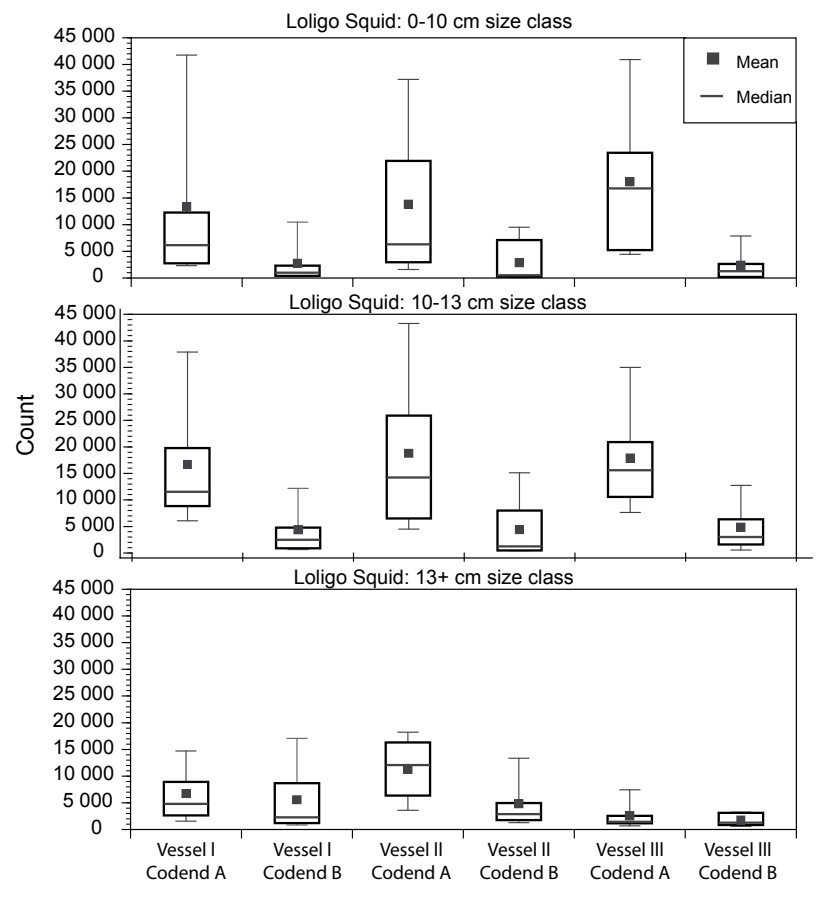

Fig. 5. Box and whisker plot of Loligo catch broken down by size class with (A) control and (B) experimental codends on three participating vessels. The box encompasses the interquartile range, with the median as the central line, the mean as the and the whiskers as the range.

size classes. Thus, of the species and size classes desired for discard reduction, the goal of discard reduction was achieved only for squid $<10 \mathrm{~cm}$. Of note, vessel effects, impacted only species without reduced catchability in the codend mesh comparisons and did not influence relative vessel performance with the two nets. Although extant in the data set, vessel effects exerted little influence on the 


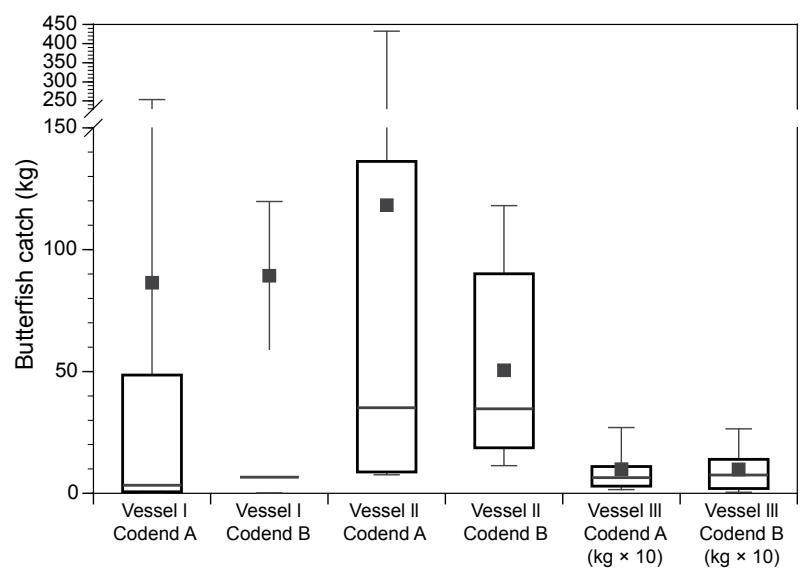

Fig. 6. Box and whisker plot of butterfish catch with (A) control and (B) experimental codends on three participating vessels. The box encompasses the interquartile range, with the median as the central line, the mean as the and the whiskers as the range.

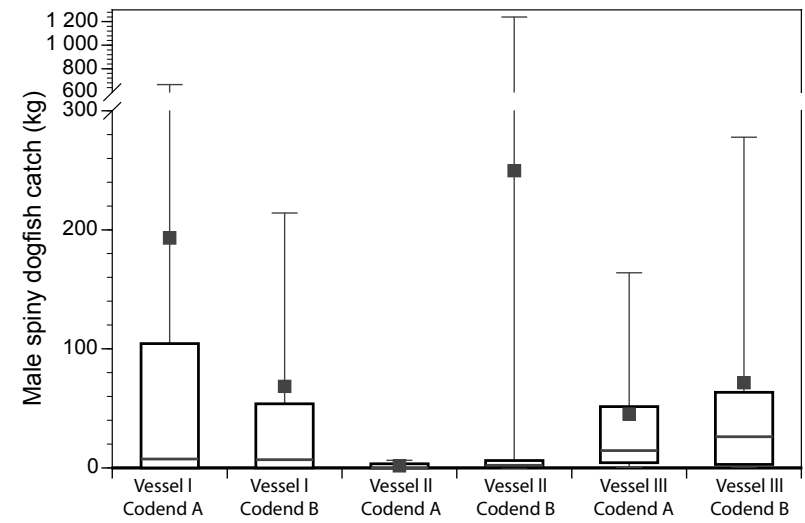

Fig. 8. Box and whisker plot of male spiny dogfish catch with

(A) control and (B) experimental codends on three participating vessels. The box encompasses the interquartile range, with the median as the central line, the mean as the and the whiskers as the range.

outcome of statistical analyses pertinent to the primary purpose of the study.

Considerable effort was expended in evaluating the differential in vessel performance to assure that vessel effects did not compromise interpretation of catch differences between codend mesh sizes. Fully one half of the tows compared the same codend simultaneously fished. These tows resolved vessel effects, particularly for spiny dogfish catch efficiency, and demonstrated equivalent performance for Loligo among vessels for both codend mesh sizes. Furthermore, the number of tows yielded adequate power as $1-\beta$ values for significant results routinely exceeded 0.75 and often 0.90 and $\beta$ values for non-significant results seldom fell below 0.70 .

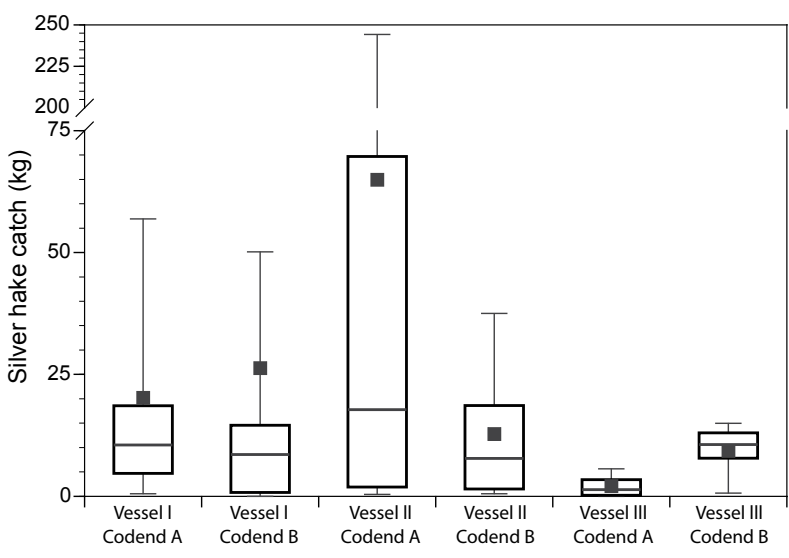

Fig. 7. Box and whisker plot of silver hake catch with(A) control and (B) experimental codends on three participating vessels. The box encompasses the interquartile range, with the median as the central line, the mean as the and the whiskers as the range.

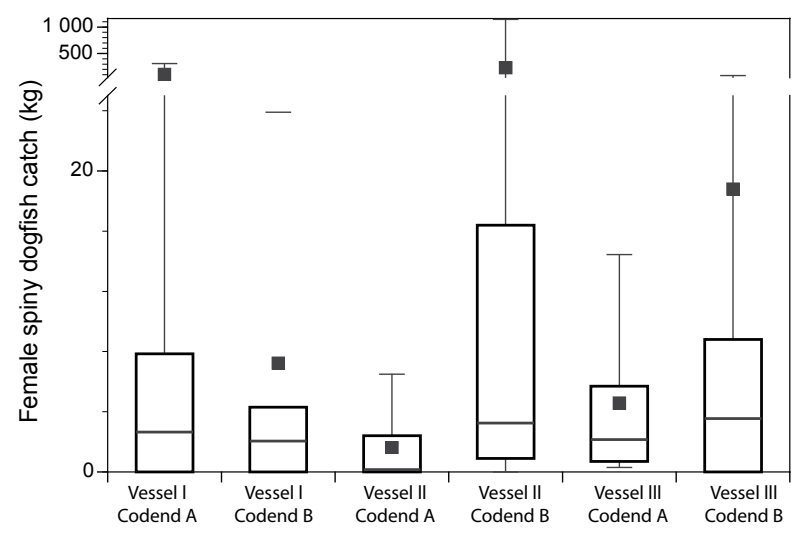

Fig. 9. Box and whisker plot of female spiny dogfish catch with

(A) control and (B) experimental codends on three participating vessels. The box encompasses the interquartile range, with the median as the central line, the mean as the and the whiskers as the range.

A change in codend mesh size is a frequently employed option to reduce discard mortality, but rarely is the influence of such a regulatory change evaluated at the fishery level. In this study, the 2.5 " codend dramatically reduced the capture of submarket-size squid, but at the cost of a decline in capture of market-size squid per hour towed. Consider the case of the median catch calculated using all tows for each of the two codend mesh sizes tested. For the control codend, the median catch of marketable squid $>10 \mathrm{~cm}$ in size was $17059 \mathrm{~kg} \mathrm{tow}^{-1}$. For the experimental codend, the median catch was $4458 \mathrm{~kg} \mathrm{tow}^{-1}$. This is a $73.9 \%$ decrease in catch of marketable squid $(>10 \mathrm{~cm})$ using the $2.5 "$ mesh. To catch the equivalent weight of marketable squid achieved by the smaller codend mesh with the larger one would require an increase in tow time 
TABLE 10. Results of ranked ANOVA on the size-frequency parameters for selected species. Codend is A or B.

\begin{tabular}{|c|c|c|c|c|c|c|}
\hline Variable & $\begin{array}{c}25^{\text {th }} \\
\text { percentile }\end{array}$ & $\begin{array}{c}50^{\text {th }} \\
\text { percentile }\end{array}$ & $\begin{array}{c}75^{\text {th }} \\
\text { percentile }\end{array}$ & Mean size & $\begin{array}{c}\text { Interquartile } \\
\text { range }\end{array}$ & Range \\
\hline \multicolumn{7}{|l|}{ Loligo squid } \\
\hline Codend & $\mathrm{P}=0.031$ & $\mathrm{P}=0.0002$ & $\mathrm{P}<0.0001$ & $\mathrm{P}<0.0001$ & $\mathrm{P}=0.0014$ & $\mathrm{P}=0.0003$ \\
\hline Cruise & $\mathrm{P}<0.0001$ & $\mathrm{P}<0.0001$ & $\mathrm{P}<0.0001$ & $\mathrm{P}<0.0001$ & $\mathrm{P}<0.0001$ & $\mathrm{P}<0.0001$ \\
\hline Codend $\times$ Cruise & - & - & - & - & - & - \\
\hline Total catch & $\mathrm{P}=0.003$ & $\mathrm{P}=0.016$ & $\mathrm{P}=0.0068$ & $\mathrm{P}=0.019$ & - & - \\
\hline \multicolumn{7}{|l|}{ Butterfish } \\
\hline Codend & - & - & - & - & - & - \\
\hline Cruise & $\mathrm{P}<0.0001$ & $\mathrm{P}<0.0001$ & $\mathrm{P}<0.0001$ & $\mathrm{P}<0.0001$ & $\mathrm{P}=0.095$ & $\mathrm{P}<0.0001$ \\
\hline Codend $\times$ Cruise & - & - & - & - & - & - \\
\hline Total catch & - & - & - & - & - & - \\
\hline \multicolumn{7}{|l|}{ Silver hake } \\
\hline Codend & - & - & - & - & - & - \\
\hline Cruise & $\mathrm{P}<0.0001$ & $\mathrm{P}<0.0001$ & $\mathrm{P}<0.0001$ & $\mathrm{P}<0.0001$ & $\mathrm{P}=0.0011$ & $\mathrm{P}=0.04$ \\
\hline Codend $\times$ Cruise & - & - & - & - & - & - \\
\hline Total catch & $\mathrm{P}=0.014$ & $\mathrm{P}=0.0003$ & $\mathrm{P}=0.0056$ & $\mathrm{P}=0.0012$ & - & - \\
\hline \multicolumn{7}{|c|}{ Female spiny dogfish } \\
\hline Codend & - & - & - & - & - & - \\
\hline Cruise & - & - & - & - & - & - \\
\hline Codend $\times$ Cruise & - & - & - & - & - & - \\
\hline Total catch & - & - & - & - & - & - \\
\hline \multicolumn{7}{|c|}{ Male spiny dogfish } \\
\hline Codend & - & - & - & - & - & - \\
\hline Cruise & $\mathrm{P}<0.0001$ & $\mathrm{P}=0.002$ & $\mathrm{P}=0.0025$ & $\mathrm{P}=0.00009$ & - & - \\
\hline Codend $\times$ Cruise & - & - & - & - & $\mathrm{P}=0.014$ & - \\
\hline Total catch & - & - & - & - & - & - \\
\hline
\end{tabular}

- not significant at $\alpha=0.05$.

of the same order. The catch of small squid in the control codend was $7753 \mathrm{~kg}^{-1}$ tow $^{-1}$. Only $959 \mathrm{~kg}^{-1}$ tow $^{-1}$ were caught by the experimental codend. Increasing effort to maintain landings volume would result in the capture of about $3670 \mathrm{~kg}$ of small squid, based on the presumed extension of swept area per trip by $73.9 \%$. This increased catch is still about half the original value. Thus, the larger mesh is advantageous in reducing discard mortality of small squid even with the requirement of the longer tow time to maintain total landings. Of course, an economic evaluation would show increased vessel costs also, so that the approach is not necessarily economically valuable, though it may be of value biologically.

However, no other species demonstrated significant reductions in catch with the larger mesh size. Thus, the discarding of juvenile butterfish, silver hake, and dogfish would increase $73.9 \%$ with the increased codend mesh size. This is diametrically opposite to the results necessary to alleviate the concerns of the influence of butterfish discards in Loligotargeted tows on the butterfish stock. Were the fishery prosecuted with the bycatch-to-target species catch ratios observed in this study, such an increase in bycatch might be insufficient to counterweigh the advantage generated by reducing the volume of juvenile squid discarded, because observed bycatches of these other species were small in this study. However, that inference would require further assessment as to the origin of the apparent dichotomy between discarding rates inferred for the Loligo squid fishery (e.g. Kennelly, 1999; NEFSC, MS 2002; Hendrickson, 2005) and those observed here and by Powell et al. (2004).

On the other hand, restricting catch volume by limiting tow duration might significantly reduce discarding of 
TABLE 11. Summary of mean, percentiles, interquartile range, and range of the size-frequency distributions (in $\mathrm{cm}$ ) for Loligo squid, butterfish, silver hake, and female and male spiny dogfish caught in each codend.

\begin{tabular}{lcccccc}
\hline \hline \multicolumn{1}{c}{ Variable } & $\begin{array}{c}25^{\text {th }} \\
\text { percentile }\end{array}$ & $\begin{array}{c}50^{\text {th }} \\
\text { percentile }\end{array}$ & $\begin{array}{c}75^{\text {th }} \\
\text { percentile }\end{array}$ & Mean size & $\begin{array}{c}\text { Interquartile } \\
\text { range }\end{array}$ & Range \\
\hline Loligo squid & & & & & & \\
Control codend & 10.00 & 11.00 & 13.00 & 11.58 & 3.00 & 12.00 \\
Experimental codend & 11.00 & 13.00 & 15.00 & 13.25 & 4.00 & 14.00 \\
Butterfish & & & & & & \\
Control codend & 14.00 & 15.00 & 15.00 & 14.81 & 2.00 & 7.00 \\
Experimental codend & 14.00 & 15.00 & 16.00 & 14.98 & 2.00 & 7.00 \\
Silver hake & & & & & & \\
Control codend & 26.00 & 27.00 & 28.00 & 27.00 & 2.00 & 8.00 \\
Experimental codend & 26.00 & 27.00 & 29.00 & 27.63 & 3.00 & 10.00 \\
Female spiny dogfish & & & & & & \\
Control codend & 57.50 & 60.50 & 63.00 & 61.49 & 5.00 & 13.00 \\
Experimental codend & 60.00 & 64.00 & 70.00 & 65.00 & 8.00 & 14.00 \\
Male spiny dogfish & & & & & & \\
Control codend & 69.00 & 72.00 & 74.50 & 71.14 & 5.00 & 19.00 \\
Experimental codend & 69.00 & 72.00 & 74.00 & 71.00 & 6.00 & 19.00 \\
\hline
\end{tabular}

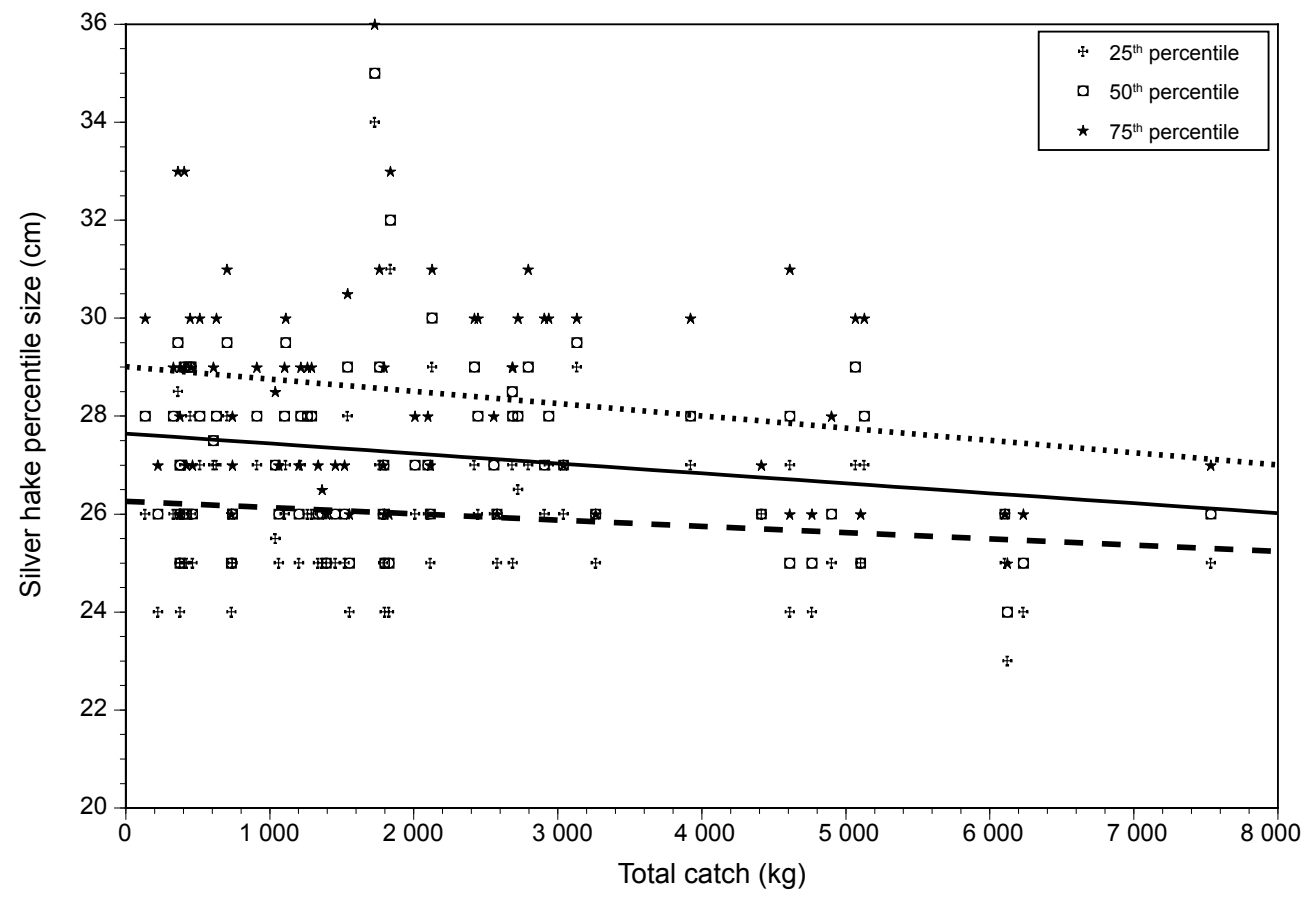

Fig. 10. The relationship between total catch and the percentiles of size for silver hake. Dashed line, the linear relationship for the $25^{\text {th }}$ percentile of size with total catch; solid line, the $50^{\text {th }}$ percentile; dotted line, the $75^{\text {th }}$ percentile. 
small silver hake, and possibly small Loligo squid. The experimental design of this study did not include varying tow duration consistently to adequately evaluate this option. However, the tendency for larger catches of silver hake and Loligo squid to have a greater fraction of small fish indicates a promising direction for future research. Modifying tow duration to limit catch volume may be one of the few options for discard management in small-mesh fisheries where an increase in codend mesh size is unlikely to limit discarding of non-target species without impacting target-species landings.

This study suggests that codend mesh size management is not necessarily an appropriate option for the Loligo squid fishery. A regulatory increase in codend mesh size to 2.5 " would lead to an increase in discarding of other species, and possibly by substantive amounts. The costto-benefit ratio achieved by the concomitant reduction in the discard mortality of juvenile squid is beyond the ambit of this analysis, but would need to be considered before a change in mesh size was introduced to address the discarding of juvenile squid. Such an estimate might include the assessment of the effect of the anticipated increase in swept area trawled (e.g., Collie et al., 1997; Jennings and Kaiser, 1998; Thrush et al., 2001) that would be an expected outcome of an increase in legal codend mesh size on the benthic communities accessed by the fishery.

\section{Acknowledgements}

We would like to express our gratitude to the owners, captains and crew of the fishing vessels Starbrite, Nightwatch, and Abracadabra, who participated in the field-sampling component of this project. This project was funded by a grant from the Mid-Atlantic Fishery Management Council's Research Set-Aside Program to the National Fisheries Institute Scientific Monitoring Committee (NFI-SMC). We appreciate the financial and logistical coordination provided by Daniel Cohen and Greg DiDomenico (NFI-SMC) and to all of the vessels who purchased and fished the Research Set-Aside quota, which funded this study.

\section{References}

ANDREW, N. L., and J. G. PEPPERELL. 1992. The by-catch of shrimp trawl fisheries. Oceanogr. Mar. Biol. Annu. Rev., 30: $527-565$.

ANON. MS 1996. Magnuson-Stevens Fishery Conservation and Management Act. NMFS NOAA Tech. Mem., NMFS-F/ SPO-23, $121 \mathrm{p}$.

BRODZIAK, J., and L. HENDRICKSON. 1998. An analysis of environmental effects on survey catches of squids Loligo pealei and Illex illecebrosus in the northwest Atlantic. Fish. Bull., 97: 9-24.

BRODZIAK, J. K. T., and W. K. MACY III. 1996. Growth of longfinned squid, Loligo pealei, in the northwest Atlantic. Fish. Bull., 94: 212-236.

BROS, W. E., and B. C. COWELL. 1987. A technique for optimizing sample size (replication). J. Exp. Mar. Biol. Ecol., 114: 63-71. doi:10.1016/0022-0981(87)90140-7

BURESCH, K. C., G. GERLACH, and R. T. HANLONN. 2006. Multiple genetic stocks of longfin squid Loligo pealei in the NW Atlantic: stocks segregate inshore in summer, but aggregate offshore in winter. Mar. Ecol. Prog. Ser., 310: 263-270. doi:10.3354/meps310263

COHEN, J. 1988. Statistical power analysis for the behavioral sciences. ( $2^{\text {nd }}$ ed.). Lawrence Erlbaum Associates, New Jersey, $585 \mathrm{p}$.

COLLIE, J. S., G. A. ESCANERO, and P. C. VALENTINE. 1997. Effects of bottom fishing on the benthic megafauna of Georges Bank. Mar. Ecol. Prog. Ser., 155: 159-172. doi:10.3354/ meps 155159

COLVOCORESSES, J. A., and J. A. MUSICK. 1983. Species associations and community composition of Middle Atlantic Bight continental shelf demersal fishes. Fish. Bull., 82: 295-313.

CONOVER, W. J. 1980. Practical nonparametric statistics. John Wiley \& Sons, New York, $493 \mathrm{p}$.

CROSS, J. N., C. A. ZETLIN, P. L. BERRIEN, D. L. JOHNSON, and C.MCBRIDE. MS 1999. Butterfish, Peprilus triacanthus, life history and habitat characteristics. NOAA Tech. Mem., NMFS-NE-145, $50 \mathrm{p}$.

DANIEL, W. W. 1978. Applied nonparametric statistics. Houghton Mifflin Company, Boston, 503 p.

FAUL, F., E. ERDFELDER, A. G. LANG, and A. BUCHNERA. 2007. G*Power 3: a flexible statistical power analysis program for the social, behavioral, and biomedical sciences. Beh. Res. Meth., 39: 175-191.

GILLIS, D. M. 1999. Behavioral inferences from regulatory observer data: catch rate variation in the Scotian Shelf silver hake (Merluccius bilinearis) fishery. Can. J. Fish. Aquat. Sci., 56: 288-296. doi:10.1139/cjfas-56-2-288

GLASS, C. W., A. H. CARR, B. SARNO., G. D. MORRIS, Y. MATSUSHITA, T. FEEHAN, and M. V. POL. 2002. Mid-Atlantic small-mesh research project. Final Report to the Mid-Atlantic Fisheries Management Council, Manomet Center for Conservation Sciences, Manomet, MA, $7 \mathrm{p}$.

GRAHAM, N., F. G. O’NEILL, R. J. FRYER, R. D. GALBRAITH, and A. MYKLEBUST. 2004. Selectivity of a $120 \mathrm{~mm}$ diamond cod-end and the effect of inserting a rigid grid or a square mesh panel. Fish. Res., 67: 151-161. doi:10.1016/j.fishres.2003.09.037

HANDEGARD, N. O., and D. TJØSTHEIM. 2005. When fish meet a trawling vessel: Examining the behaviour of gadoids using a free-floating buoy and acoustic split-beam tracking. Can. J. Fish. Aquat. Sci., 62: 2409-2422. doi:10.1139/ f05-131

HASTIE, L. C. 1996. Estimation of trawl codend selectivity for squid (Loligo forbesi) based on Scottish research vessel 
survey data. ICES J. Mar. Sci., 53: 741-744. doi:10.1006/ jmsc. 1996.0093

HENDRICKSON, L. 2005. Effectiveness of a square-mesh escape panel in reducing finfish bycatch in a small-mesh bottom trawl used in the longfin inshore squid (Loligo pealeii) fishery. NEFSC Ref. Doc. 05-05, 37 p.

JENNINGS, S., and M. J. KAISER. 1998. The effects of fishing on marine ecosystems. Adv. Mar. Biol., 34: 201-352. doi:10.1016/S0065-2881(08)60212-6

JENSEN, A. C. 1965. Life history of the spiny dogfish. Fish. Bull., 65: 527-554.

KARP, W. A., C. S. ROSE, J. R. GAUVIN, S. K. GAICHAS, M. W. DORN, and G. O. STAUFFER. 2001. Governmentindustry cooperative fisheries research in the North Pacific under the MSFCMA. Mar. Fish. Rev., 63 (1): 40-46.

KENNELLY, S. J. 1999. Areas, depths and times of high discard rates of scup, Stenotomus chrysops, during demersal fish trawling off the northeastern United States. Fish. Bull., 97: 185-192.

KYNOCH, R. J., M. C. O'DEA, and F. G. O'NEILL. 2004. The effect of strengthening bags on cod-end selectivity of a Scottish demersal trawl. Fish. Res., 68: 249-257. doi:10.1016/j.fishres.2003.12.003

LANGE, A. M. T. 1980. Yield per recruit analysis for squid, Loligo pealei and Illex illecebrosus. NEFSC Lab. Ref. Doc., 80-03, 9 p.

LÖK, A., A. TOKAÇ, Z. TOSUNOĞLU, C. METIN, and R. S. T. FERRO. 1997. The effects of different cod-end design on bottom trawl selectivity in Turkish fisheries of the Aegean Sea. Fish. Res., 32: 149-156 doi:10.1016/S0165-7836(97)00048-9

MACY, W. K. III, and J. K. T. BRODZIAK. 2001. Seasonal maturity and size at age of Loligo pealeii in waters of southern New England. ICES J. Mar. Sci., 58: 852-864. doi:10.1006/jmsc.2001.1076

MILLAR, R. B., M. K. BROADHURST, and W. G. MACBETH. 2004. Modelling between-haul variability in the size selectivity of trawls. Fish. Res., 67: 171-181. doi:10.1016/j. fishres.2003.09.040

MURAWSKI, S. A. 1993. Climate change and marine fish distributions: forecasting from historical analogy. Trans. Am. Fish. Soc., 122: 647-658. doi:10.1577/15488659(1993)122<0647:CCAMFD >2.3.CO;2

1996. Factors influencing by-catch and discard rates: analyses from multispecies/multifishery sea sampling. $J$. Northw. Atl. Fish. Sci., 19: 31-39. doi:10.2960/J.v19.a3

NEFSC. MS 2000. $31^{\text {st }}$ northeast regional stock assessment workshop $\left(31^{\text {st }} \mathrm{SAW}\right)$ : Stock assessment review committee (SARC) consensus summary of assessments. NEFSC Ref. Doc. 00-15, $400 \mathrm{p}$.

MS 2002. $34^{\text {th }}$ northeast regional stock assessment workshop ( $\left.34^{\text {th }} \mathrm{SAW}\right)$ : Stock assessment review committee (SARC) consensus summary of assessments. NEFSC Ref. Doc., 02-06, 346 p.

MS 2004. $38^{\text {th }}$ northeast regional stock assessment workshop (38 $\left.{ }^{\text {th }} \mathrm{SAW}\right)$ : Stock assessment review committee
(SARC) consensus summary of assessments. NEFSC Ref. Doc., 04-03, 246 p.

PENTTILA, J. A., G. A. NELSON, and J.M. III. BURNETT. MS 1989. Guidelines for estimating lengths at age for 18 Northwest Atlantic finfish and shellfish species. NOAA Tech. Mem., NMFS-F/NEC-66, 44 p.

POWELL, E. N., A. C. BONNER, and E. A. BOCHENEK. MS 2003. Scup discarding in the fisheries of the Mid-Atlantic Bight. Final Report to the New Jersey Fisheries Information and Development Center, Final Report to the Mid-Atlantic Fisheries Management Council Research Set-Aside Program, Project \#NA16FM2268, 59 p.

POWELL, E. N., A. J. BONNER, B. MULLER, and E. A. BOCHENEK. 2004. Assessment of the effectiveness of scup bycatch-reduction regulations in the Loligo squid fishery. J. Environ. Manage., 71: 155-167. doi:10.1016/j. jenvman.2003.12.016

RAGO, P. J., K. A. SOSEBEE, J. K. T. BRODZIAK, S. A. MURAWSKI, and E. D. ANDERSON. 1998. Implications of recent increases in catches on the dynamics of Northwest Atlantic spiny dogfish (Squalus acanthias). Fish. Res., 39: 165-181. doi:10.1016/S0165-7836(98)00181-7

RAGONESE, S., M. ZAGRA, L. DI STEFANO, and M. L. BIANCHINI. 2001. Effect of codend mesh size on the performance of the deepwater bottom trawl used in the red shrimp fishery in the Strait of Sicily (Mediterranean Sea). Hydrobiologia, 449, 279-291. doi:10.1023/A:1017564530716

RAGONESE, S., M. L. BIANCHINI, and L. DI STEFANO. 2002. Trawl cod-end selectivity for deepwater red shrimp (Aristaeomorpha foliacea) in the Strait of Sicily (Mediterranean Sea). Fish. Res., 57: 131-144. doi:10.1016/ S0165-7836(01)00342-3

SERCHUK, F. M., and W. F. RATHJEN. 1974. Aspects of the distribution and abundance of the long-finned squid, Loligo pealei, between Cape Hatteras and Georges Bank. Mar. Fish. Rev., 36 (1): 10-17.

SHEPHERD, G. R., and M. TERCEIRO. MS 1994. The summer flounder, scup, and black sea bass fishery of the Middle Atlantic Bight and southern New England. NOAA Tech. Rpt., NMFS 122, 13 p. http://spo.nwr.noaa.gov/tr122.pdf

SOKAL, R. R., and F. J. ROHLF. 1998. Biometry: The principles and practice of statistics in biological sciences. ( $3^{\text {rd }}$ ed.). W.H. Freeman, New York, 887 p.

THOMAS, L., and C. J. KREBS. 1997. A review of statistical power analysis software. Bull. Ecol. Soc. Am., 78: 126-139.

THRUSH,S.F.,J.E.HEWITT, G.A.FUNNELL, V.J.CUMMINGS, J. ELLIS, D. SCHULTZ, D. TALLEY, and A. NORKKO. 2001. Fishing disturbance and marine biodiversity: The role of habitat structure in simple soft-sediment systems. Mar. Ecol. Prog. Ser., 223: 227-286. doi: $10.3354 / \mathrm{meps} 223277$

WALSH, S. J. 1988. Diel variability in trawl catches of juvenile and adult yellowtail flounder on the Grand Banks and the effect on resource assessment. N. Am. J. Fish. Manage., 8: 373-381. doi:10.1577/15488675(1988)008<0373:DVITCO >2.3.CO;2 